\title{
A política econômica do governo Médici: 1970-1973
}

José Pedro Macarini Professor do Instituto de Economia da Unicamp

\begin{abstract}
Palauras-chave
Brasil, ditadura militar, política econômica.
\end{abstract}

Classificação JEL E65.

\section{Key words \\ Brazil, military dictatorship, economic policy.}

JEL Classification E65.

\section{Resumo}

Este artigo examina a política econômica durante o governo de Emílio Garrastazu Médici, período que se tornou conhecido pela descrição oficial do auge cíclico então em curso como se fora um ciclo desenvolvimentista capaz de prolongar-se por décadas projetando a superação do atraso. $\mathrm{Na}$ primeira parte, examina-se a gestação de um projeto nacional pelo regime, desaguando no projeto Brasil Grande Potência, o qual se apoiou no modelo "agrícola-exportador" como a sua estratégia de desenvolvimento. $\mathrm{Na}$ segunda parte, procede-se a uma detalhada reconstituição da execução da política econômica com ênfase nos aspectos relacionados à concepção estratégica anunciada, à sustentação do crescimento e ao tratamento dispensado à inflação. A análise evidencia alguns aspectos peculiares da conjuntura 1972-1973, sugerindo tratar-se de um momento distinto (uma segunda fase) da administração Médici.

\section{Abstract}

This article focuses on the economic policies of the Emilio Garrastazu Medici administration. This period became known for the official description of the then ongoing economic boom, as if this boom were a real developmental stage that would lead to prolonged growth for decades, thus pulling the country out of its backwardness. In the first section, we will examine the creation of a national project by the military regime, leading to the "Brazil: a Great Power" project, which was based on growth in exports of agricultural products as its core development strategy. The second section presents a detailed summary of the conduct of economic policy with emphasis given to aspects concerning the core strategy announced, to sustained growth and to stabilization policy. The analysis highlights some specific aspects of the 1972-1973 economic scenario, suggesting that this represents a different period (a second phase) in the conduct of economic policy during the Brazilian "miracle". 


\section{1_Introdução}

A evolução da economia brasileira e da política econômica durante o regime militar foi objeto de freqüente atenção dos estudiosos, o que permitiu consolidar profundo conhecimento acerca do período. Algumas lacunas permanecem, porém. Uma delas diz respeito à política econômica do governo Médici. O objetivo deste artigo é contribuir para um conhecimento mais aprofundado deste tema.

A literatura existente tendeu a tratar em bloco, como se fora um continuum, o período mais longo iniciado em 1967 (governo Costa e Silva) e abarcando o governo Médici. Esse enfoque terá sido estimulado por fatores como a continuidade de comando da política econômica sob Delfim Netto, a explícita inflexão promovida em 1967-68, a predominância de uma orientação expansionista na maior parte do período - e a conjuntura de crescimento acelerado, descrito à época na imagem do "milagre brasileiro".

Contudo, tal perspectiva, conquanto adequada para certos propósitos, não configura um retrato fiel do movimento da política econômica, o qual foi bem mais complexo e não-linear. Assim, o discurso (e a práxis) delfiniana de 1967 1968 não se projetam facilmente sobre todo o período até 1973; é possível argu- mentar que uma nova inflexão da política econômica ocorreu em 1969 (sob o efeito da mudança de conjuntura política decretada pelo AI-5); o "milagre" desponta apenas na virada de 1969 para 1970; a "visão de mundo" delfiniana (o "modelo agrícola-exportador") somente adquire o estatuto de núcleo estratégico da política econômica no governo Médici - e discrepa da visão elaborada no Planejamento; e o impressionante expansionismo da política econômica de curto prazo em 1972-1973 se fez num cenário totalmente distinto do observado em 1967-1968, devendo ser apreciado nesse contexto. Nesse sentido, a leitura proposta neste artigo enfatiza as descontinuidades reveladas pelo movimento da política econômica da ditadura.

Este artigo se propõe examinar a política econômica do governo Médici nos seguintes aspectos;

1. a sua orientação estratégica, materializada no projeto Brasil Grande Potência e tendo o "modelo agrícola-exportador" de Delfim Netto como a sua base de apoio: a sua reconstituição requer breves referências a episódios anteriores da política econômica (o PAEG do governo Castello Branco, e o PED do governo Costa e Silva); 
1 isso foi observado,

Isso foi observado, já em 1965, num debate "interno" do PAEG.

Ver Dias Leite (1965).

2 Convém lembrar que o governo Castello Branco também produziu, em 1966, o Plano Decenal, uma coleção de estudos setoriais embasados numa perspectiva de planejamento para toda uma década. O governo Costa e Silva, originado de uma disputa interna ao regime, responsável por uma mudança substantiva na condução da política macroeconômica, abandonou o Decenal para elaborar o seu próprio plano. Uma apreciação do Plano Decenal permanece em aberto, não tendo sido abordada neste artigo. Para uma introdução ao tema, ver Ianni (1977, p. 225-239).
2. a execução da política econômica de 1970 a 1973, com referência seja aos aspectos diretamente relacionados àquela orientação estratégica, seja à evolução da conjuntura; um tratamento à parte é dispensado ao subperíodo 19721973, tendo em vista as características específicas dessa conjuntura.

A pesquisa realizada trabalhou fundamentalmente com a literatura geral e especializada relativa ao tema, documentos oficiais do período e artigos e entrevistas das autoridades econômicas publicados em jornais e revistas. $\mathrm{O}$ artigo compõe-se de quatro seções: esta introdução, a reconstituição da estratégia de desenvolvimento, o exame da execução da política econômica ao longo do período e algumas considerações finais.

\section{2_A estratégia de desenvolvimento}

\section{1_Gestação do projeto nacional: Brasil Grande Potência}

A ideologia político-econômica tecida durante o governo Castello Branco foi composta de ingredientes muito singelos: na linha de frente, o combate sem trégua à inflação (a origem de todos os males), acompanhado do repúdio à tentação estatista - assim, num cenário de estabilidade e livre-iniciativa, brotaria com pleno vigor a nova racionalidade, alicerce firme do desenvolvimento. Este teria, ainda, outro pilar no reconhecimento das virtudes da internacionalização que, esperava-se, agora prosseguiria sem entraves de espécie alguma. Seja porque efetivamente se acreditasse numa fácil retomada do desenvolvimento uma vez superada a barreira da inflação, seja porque de início o horizonte de permanência do novo regime era incerto mesmo para os seus artífices, o fato é que inexistiu ou teve papel secundário qualquer perspectiva explícita de elaboração de um projeto próprio de construção da Nação. ${ }^{1}$

Isso muda completamente nos anos 1967-1969, com o discurso político-econômico se apropriando da idéia de construção de um projeto nacional visando "responder de forma adequada ao desafio brasileiro", qual seja "demonstrar a viabilidade do desenvolvimento brasileiro" (PED: I-2). ${ }^{2}$ Tal preocupação permeia o Programa Estratégico de Desenvolvimento (PED), lançado pelo governo Costa e Silva em 1968. Contrastando flagrantemente com a retórica anterior do PAEG, o PED se apoiou num diagnóstico que vinculava o "desafio brasileiro" ao "arrefecimento da substituição de im- 
portações", encerrando um estágio do processo de desenvolvimento econômico do Brasil, caracterizado por uma estratégia baseada num "único fator dinâmico" (a indústria), tornada possível pelo fato de a decisão de investir depender "apenas do tamanho absoluto dos mercados". A resposta do PED ao desafio de "assegurar a retomada da trajetória de desenvolvimento acelerado" consistiu na proposta de "um novo modelo de desenvolvimento". Como a decisão de investir passava a depender essencialmente das expectativas de crescimento dos mercados (e não mais "apenas" do seu "tamanho absoluto"), era necessário identificar corretamente e apoiar os setores dinâmicos aptos a dar sustentação ao crescimento econômico. A novidade estaria no caráter "multissetorial" do novo estágio de desenvolvimento. Essa proposição é formulada da seguinte forma:

Exatamente porque arrefeceu a substituição de importações e nenhuma estratégia concentrada numa única fonte de dinamismo terá condições de assegurar o desenvolvimento auto-sustentável, a estratégia a adotar no novo estágio objetiva a diversificação das fontes de dinamismo. Dever-se-á ampliar substancialmente o 'bloco' de setores dinâmicos interligados, e que na fase anterior se limitara praticamente à Indústria (Bens de capi- tal, Bens de consumo duráveis, Bens intermediários) e alguns segmentos de Infra-estrutura e de Agricultura. A ampliação desse "bloco" de impactos simultâneos, para abranger (além da Indústria) o Setor Agrícola, áreas substanciais da InfraEstrutura Econômica e da própria InfraEstrutura Social (Habitação, Educação, Saneamento) irá permitir a expansão da demanda e oferta capaz de sustentar um ritmo intenso de crescimento, numa ampliação de mercado que permita superar a fase de crescimento moderado em que se encontrava a economia (PED: IV-16).

O PED não deixa dúvidas quanto à necessidade de diversificar as fontes de dinamismo:

O elemento essencial a salientar é que somente a ação simultânea naquelas quatro áreas dinâmicas, com a ênfase adequada em cada uma, mobilizará do lado da demanda e do lado da oferta os fatores indispensáveis a um crescimento do produto da ordem de 6\% ao ano (PED: IV-16).

Atente-se para o fato de, em 1968, a política econômica estar engajada na elaboração de uma nova estratégia de desenvolvimento que projetava um crescimento do produto de "no mínimo, $6 \%$ ao ano, no período 1968-1970" (estimando-se viável um crescimento levemente acima, dada a prevalência de capacidade ociosa generalizada) (PED: II-2 e IV-11). 
$\cdots \ldots \ldots \ldots$

3 Não apenas a expansão do emprego e a melhoria de produtividade, mas igualmente uma política de distribuição impulsionaria o surgimento desse mercado de massa.

4 "Nação Armada contribuirá para que esta verdade seja percebida, formulada e realizada. É óbvio o nosso empenho em alinhar os elementos técnicos (econômicos, sociais e políticos) do PROJETO BRASILEIRO que é, sobretudo, o conjunto de diretrizes e alternativas que ordenarão os esforços da Sociedade e do Estado para que a Nação realize a sua vocação e o seu Destino". Todas as citações são extraídas do Programa de Nação Armada, republicado no n. 3, junho de 1968 .
E é claro que um dos setores dinâmicos continuaria a ser a indústria de transformação, para isso sendo necessário diversificar suas fontes de expansão: substituição de importações ("enquanto racionalmente possível”), expansão do mercado interno, promoção de exportações. Em alguns momentos, uma formulação mais contundente transparece: $\mathrm{O}$ mercado interno é a ferramenta mais importante de que dispomos para conseguir o nosso desenvolvimento. Cumpre ao Governo fortalecê-lo e expandi-lo (Diretrizes de Governo: 15). Nessa linha, uma política de distribuição de renda integra a estratégia e vislumbra-se a criação de um "mercado de massa" como condição do desenvolvimento acelerado e auto-sustentado. O PED esclarece que tal mercado de massa é entendido

no sentido de que considerável percentagem da população urbana e rural tenha nivel de renda capaz de permitir consumo habitual de bens industriais, principalmente não duráveis, que sustente o crescimento das Indústrias Tradicionais a taxas próximas das do crescimento do PIB (PED: IV-11). ${ }^{3}$

Uma menção deve ser feita ao ambiente político-ideológico observado nas hostes do regime militar nos anos finais da década de 60. Nesse período, tendeu a ganhar densidade a reflexão doutrinária acerca do real significado da Revolução de 1964, numa linha que podemos designar, não obstante a sua manifestação difusa, de "nacionalismo autoritário". Um exemplo lapidar foi a revista Nação Armada, surgida nesse momento e explicitando em seu programa o propósito de dedicar-se "ao debate interpretativo e ao ideário da Revolução" para assim chegar ao "conhecimento" e à "doutrina da Revolução" (esta, note-se, não havia sido explicitada nem em 1964, nem durante o governo Castello Branco). O "conhecimento" perseguido dizia respeito ao sentido da Revolução de 64, qual seja, atualizar

uma VOCACÃO e um DESTINO: a liderança continental de uma Revolução e a afirmação mundial de uma grande Potência.

Para ensejar esse "conhecimento" e sua concretização através de um "projeto brasileiro" surgia Nação Armada, correia de transmissão dos ideais e anseios da elite pensante do regime aos "setores revolucionários no Governo ou fora dele". ${ }^{4}$

Talvez a liderança mais expressiva do nacionalismo autoritário nesse período tenha sido o general Albuquerque Lima, ministro do Interior em 1967-1968, crítico da política econômica delfiniana 
pós-AI-5 e candidato à sucessão de Costa e Silva. Seu discurso se caracterizou por associar enfaticamente a Revolução de 1964 à tarefa de realizar "grandes reformas e transformações sociais", vistas como passagem obrigatória para o pleno desenvolvimento da Nação. Este se via contido graças à alta concentração de renda e pobreza, afetando, sobretudo, algumas regiões, o que tornava limitado o mercado interno - assim, se contrapunham o interesse nacional e os interesses de oligarquias, estes últimos sempre solidamente incrustados no aparelho político-institucional.

Ousar enfrentar as oligarquias para varrer estruturas arcaicas, tal era, ao que parece, um elemento central da concepção do general Albuquerque Lima haja vista sua defesa da reforma agrária, considerada "condição primordial do crescimento industrial e criadora de amplo mercado interno". Através da "incorporação da massa brasileira", tornar-se-ia possível superar o atraso, atualizando o sonhado destino de grandeza. A contribuição do capital estrangeiro é valorizada, mas não de forma incondicional, acenando-se o propósito de estabelecer controles. Apoiar a empresa nacional visando ao seu fortalecimento constituía outra preocupação explícita do seu ideário. ${ }^{5}$

As reflexões cultivadas pelos ideólogos do nacionalismo autoritário rece- beram estímulo adicional e ganharam maior ressonância com a penetração alcançada por alguns estudos produzidos no exterior - a saber, a tese da supremacia absoluta dos EUA, fundada em seu domínio da tecnologia (popularizada em O desafio americano, de Servan-Schreiber), e as projeções futuristas promovidas por uma instituição norte-americana (sintetizadas em $O$ ano 2000, de Herman Kahn), as quais insistiam em ignorar o destino de grandeza reservado à nação brasileira. É sintomático que o tema do "desafio tecnológico" se tenha tornado ingrediente importante da retórica do Planejamento nos anos seguintes, enquanto a intelligentsia oficial contra-atacou maciçamente as projeções de Kahn relativas ao Brasil. ${ }^{6}$

Não será demais reafirmar: a recuperação da economia que iria prosseguir sem interrupção, desdobrando-se em vigoroso auge cíclico, havia começado em meados de 1967; não obstante, até o segundo semestre de 1969, a própria política econômica do regime não se mostrava segura na avaliação do processo em curso; as ambições explicitadas não iam além da recuperação da trajetória histórica de crescimento (PED). A propagação de um estado de inquietação latente, uma espessa névoa recobrindo o futuro sonhado, se não chegava a colocar um risco real de guinada profunda na orientação do regi-

\footnotetext{
Todas as citações são extraídas de matéria da revista Visão, 24-10-69, resumindo um documento inédito de Albuquerque Lima no qual esboça um programa de governo. Para uma breve discussão do nacionalismo autoritário, ver Vinhas de Queiroz (1973).

6 Ver Reis Velloso, entrevista à revista Veja, 18-6-69. Ver também seu texto "O Desafio Tecnológico e o Projeto Brasileiro" (set./69), divulgado pelo Planejamento. No âmbito acadêmico, Simonsen daria a sua contribuição ao debate escrevendo o livro Brasil 2001 - ver Simonsen (1969).
} 
Ver "A crise institucional", in $O$ Estado de S. Paulo, 26-10-69.

8 Ver Médici (1970). me, criava, porém, a necessidade de uma resposta para acomodar as "bases" (mesmo porque, como é sabido, a "eleição" do general Médici ocorreu em detrimento justamente da candidatura nacionalista de Albuquerque Lima). Enquanto manifestação retórica, a estratégia de desenvolvimento do período 1970-1973 só se torna compreensível quando se tem em conta esses desdobramentos. Mas há um dado adicional freqüentemente ignorado: data do início de 1970 (ou final de 1969) a tomada de consciência do vigor da recuperação em curso, o que permitiu à política econômica mudar sua anterior postura cautelosa e sóbria, passando a apostar "alto", em consonância com as aspirações políticas do novo governo. Assim surgiria o projeto Brasil Grande Potência, visando trazer à luz, até o ano 2000, o pretendido destino nacional de grandeza. ${ }^{7}$

Desde o primeiro momento, o discurso de Médici revelou afinidades inequívocas com os anseios de grandeza. Em sua mensagem de 7 de outubro de 1969, diria: “O Brasil é grande demais para tão poucas ambições”. Estas se insinuavam no reconhecimento da meta de "triunfo final na arrancada para o desenvolvimento econômico e social". Em seu discurso de posse, reiteraria: "Homem de meu tempo, tenho pressa". Um ritmo de crescimento oscilando entre 6 e $7 \%$ “já não nos bastam”, "urge acelerar o processo". E ainda:

Creio no apressamento do futuro. E creio em que, passados os dias dificeis dos anos 60, amanhecerá, na década de 70, a nossa hora. ${ }^{8}$

A orientação a ser imprimida à política econômica do novo governo permaneceu indefinida durante alguns meses. Uma leitura atenta das manifestações dos atores principais envolvidos na sua elaboração e a cobertura feita pela grande imprensa permitem especular que uma disputa interna (no mínimo um "debate") tenha ocorrido contrapondo Fazenda e Planejamento. Reis Velloso, que em seu discurso de posse havia anunciado para breve a divulgação de um documento explicitando as grandes diretrizes da política econômica - as "Bases da Política do Governo", continuaria a advogar uma linha de ação totalmente afinada com o ideário já explicitado no PED. A retórica elaborada por Velloso apresentava uma "visão telescópica”, alcançando o ano 2000 (período estimado para o nosso "ingresso na sociedade dos desenvolvidos"), e era francamente desenvolvimentista ao alertar para o papel decisivo atribuído ao novo governo (1970-1973): 
A incapacidade de assegurar o desenvolvimento acelerado nesse periodo poderá sacrificar irremediavelmente as perspectivas de longo prazo.

O otimismo de Velloso - seu discurso pode ser lido como se afirmasse: "Sim, podemos ambicionar o pleno desenvolvimento" - era, contudo, temperado pela prudência na hora de definir o ritmo almejado do crescimento (ao alertar para o risco das "formulações irrealistas"). ${ }^{9} \mathrm{Se}$ isso bastava para emudecer as vozes de cassandra da ortodoxia econômica, sempre inconformadas com a longa permanência da inflação (mesmo após o "ataque mortal" que a política econômica pretendera executar durante 1969), é lícito supor que ainda estava aquém do demandado por um governo que nascia sob o signo da "pressa".

Outra foi a postura exibida por Delfim Netto nessa conjuntura. Antes de mais nada, em plena consonância com os anseios voluntaristas do novo grupo dirigente, Delfim terá sido a primeira autoridade econômica a ousar defender uma meta de crescimento da ordem de $9 \%$ ao ano. Por suposto, o fascínio exercido por tal perspectiva de crescimento colocava em efetivo segundo plano as preocupações com a inflação persistente (que contraste com a experiência vivida ao longo de 1969!). Por outro lado, ele brandia (no começo, discretamente) a sua própria es- tratégia de desenvolvimento: a aceleração do desenvolvimento seria assegurada pelo apoio simultâneo à agricultura e à exportação, configurando um novo modelo de desenvolvimento. ${ }^{10}$

É bastante sugestivo que a divulgação das grandes diretrizes do novo governo, reiteradamente anunciada para dezembro, tenha sido adiada para a reunião ministerial de 6 de janeiro de 1970 , ocasião em que nada foi decidido. A julgar pela cobertura da grande imprensa, o documento preparado no Planejamento teria despertado acentuada reação crítica; ademais, teria aflorado o desencontro de opiniões no tocante à meta de crescimento a ser adotada, sob o impacto da apresentação das estatísticas revistas de crescimento relativas a 1968 e $1969 .{ }^{11}$

Uma leitura superficial da política econômica, induzida pela forma imprimida aos sucessivos documentos produzidos pelo regime, sempre preocupados em tecer uma linha de continuidade inaugurada em 1964, tenderia a desprezar os indícios de mudança e debate de alternativas. Tanto mais que a atividade do Planejamento frutificou, dando origem às Metas e Bases para a Ação do Governo (documento divulgado em outubro de 1970). Uma leitura atenta, entretanto, sugere que as Metas e Bases (e o posterior I PND) cumprem papel essencialmente retórico, não se constituindo no guia da política econômica do
......

9 Ver, por exemplo:

"Desenvolvimento e

Planejamento" (nov./69), "As

Grandes Realizações Nacionais" (dez./69) e "Projeto Nacional, Planejamento e Perspectivas"

(O Estado de S. Paulo e Jornal do Brasil, 30/12/69).

10 Ver as declarações de Delfim, reproduzidas in $\mathrm{O}$

Estado de S. Paulo, 15/11/69, 30/11/69 e 9/12/69.

11 A revista $V$ eja, 14/1/70, faz um relato da primeira reunião ministerial, colocando o ministro numa posição muito incômoda; a matéria vai ao ponto de relatar uma suposta divergência quanto ao crescimento do PIB: "Velloso falara em 6 a $7 \%$ e na reunião ministerial Delfim prometera entre 8 a 9\% para 1970, depois Velloso voltaria a carga com $10 \%$ ". Reis Velloso responderia à revista, esclarecendo: "1. É inexata a informação de que o Sr. Presidente da República teria ficado 'extremamente irritado' com o texto do documento de 'bases'; 2. É inexata a informação de que [...] o Presidente haja mudado o sentido da reunião para reduzir a evidência da exposição do Ministro do Planejamento; 3. É inexata a informação de que o Ministro do Planejamento teria alterado a meta de crescimento [...] de $6 / 7 \%$ para 10\%". Veja, 21/1/70. 
governo Médici. Com efeito, a ação do Planejamento, tão bem ilustrada pelo PED (1968) e pelo II PND (1974), foi sufocada pela perspectiva dominante durante o " $\mathrm{mi}$ lagre" fielmente traduzida na máxima de Delfim Netto: "Dêem-me o ano, e não se preocupem com décadas". ${ }^{12}$

E não há como negar que a orientação da política econômica foi, sim, decidida naqueles meses iniciais. Ainda em janeiro de 1970, Delfim tornaria pública a nova opção estratégica, o modelo "agrícola-exportador”. E em março o próprio general Médici ratificaria a escolha da opção delfinista ao comunicar a sua política de desenvolvimento:

\section{Ai estará, precisamente, a maior novida- de da nova politica governamental. Desde os anos 50, nosso esforço desenvolvimen- tista vem sendo predominantemente indus- trial, de forma desequilibrada em relação ao setor agrícola [...] Dessa forma, nossa política de desenvolvimento [...] visará ao}

incremento substancial da produção agricola e ao aumento das exportações, o que certamente haverá de motivar rápida ampliação do mercado interno e induzirá a própria expansão do setor industrial.

E esclareceria em definitivo a meta de crescimento de seu governo: "Esperamos acelerar a marcha do desenvolvimento em ritmo de crescimento da ordem de $10 \% "{ }^{13}$

\section{2_O modelo "agrícola-exportador"}

O início do governo Médici será marcado por acentuada dominância dessa concepção que, embora já esboçada anteriormente (sobretudo a partir de 1967), não desfrutava até então de semelhante primazia. Agora, passa a se constituir no núcleo mesmo da política de desenvolvimento e do modelo de crescimento adotados - desenha-se, assim, em sua plenitude, o novo modelo "exportador" (ou, mais precisamente, "agrícola-exportador"), formulação

\footnotetext{
12 Esse é o título de um artigo de Delfim publicado no Jornal do Brasil, 31/3/70. A meu ver, o mais significativo é o momento escolhido para comunicar essa "visão de mundo", francamente hostil à atividade de planejamento. $\mathrm{O}$ próprio general Médici vinha indicando um apreço menor por diagnósticos e programação; em sua
}

Mensagem de 31/12/69, afirmou: "Convencido estou da menor necessidade de novos planos que de determinação e constância para acionar e aperfeiçoar o que planejado existe". (Médici, 1970, p. 82). Um editorial de $\mathrm{O}$ Estado de $S$. Paulo (23/12/69) atacaria a "planomania" - para concluir: “[...] a inflação de planos provocou sua desvalorização perante os técnicos. E o público propriamente dito já não liga". Reis Velloso reconheceria o surgimento de um ambiente marcado pela "insistência em mais execução e menos planejamento" e buscaria defender a importância crucial do planejamento (Ver seu artigo em O Estado de S. Paulo, $31 / 12 / 69)$. 13 Aula inaugural na ESG - in O Estado de S. Paulo, 11/3/70. O fortalecimento de Delfim já era insinuado em matéria da revista $V_{e j a}, 14 / 1 / 70$. Após a precoce saída do ministro Fábio Yassuda, a revista Visão, 14/3/70, comentaria: "Na verdade, Delfim Netto surgiu como figura dominante na área econômico-financeira”. 
associada a Delfim Netto. Convém examinar a questão com algum detalhe.

Um notável (e ignorado) documento desse período delineia a tarefa da quadra histórica que se anunciava:

Cabe agora, num verdadeiro programa de emergência para o Brasil, fixar a opondo às crises de motivação e às frustrações do passado a confiança no projeto brasileiro e a vontade de toda a Nação de realizar o pleno desenvolvimento.

(Esse "projeto brasileiro" envolvia a ambição explicitada tranqüilamente de dobrar a renda per capita de 1970 a 1980, apoiada numa projeção de crescimento do PIB de 9\% a. a. - "indiscutivelmente viável nas atuais condições econômicas do país").

O sucesso na implementação desse "projeto brasileiro" exigiria "alterações substanciais na estratégia de desenvolvimento", de forma a permitir "evitar a repetição das falácias que têm obstado a construção de um país grande, livre e progressista". Assim:

Essa aceleração do crescimento resultaria de uma modificação substancial na estratégia do desenvolvimento, que passaria a centrar-se [...] no forte incremento da produção agricola e das exportações do país, ensejando a rápida ampliação do mercado interno e induaindo o crescimento dos demais setores.
Tal estratégia [...] se orienta no sentido de um crescimento equilibrado, com as virtudes inerentes a esse processo, que, pelo desenvolvimento simultâneo dos diversos setores, acelera a criação de renda e de mercado para cada um desses setores.

$\mathrm{O}$ aspecto chave da estratégia era: "Centrar-se, a curto e médio prazo, no aumento e exportação simultânea da produção agrícola”. Essa era a resposta delfiniana para as recorrentes preocupações com o tamanho (insuficiente) do nosso mercado interno: lembre-se, o PED discorria sobre a necessidade de criar o "mercado de massa", Albuquerque Lima acenava com a reforma agrária (falácia?).

Dos dois setores básicos - agricultura e exportações - surgirão condição para uma rápida ampliação do mercado interno.

$\mathrm{O}$ argumento - central - é reiterado:

Não existem fórmulas mágicas de ampliação do mercado interno. Esta depende, para sua mais rápida concretização, de um elemento exógeno ao sistema, representado pelo mercado externo que permitirá um aumento geral da produtividade.

Ainda uma vez: "Do setor exportador provirá o elemento dinâmico para alteração de todo o quadro da economia brasileira". Dessa forma, pretende-se viável o desenvolvimento almejado, posto que "a estratégia confere à economia o elemento 


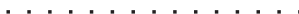

14 As citações são do

Programa da Política

Econômica do Governo. Esse documento, ao que parece, jamais foi oficialmente divulgado. Mas uma edição na forma de apostila, sem referências precisas de data e precedência, foi utilizada no curso de Economia Brasileira da FEA-USP em 1975 sob a responsabilidade do Professor Carlos Viacava (anteriormente um integrante da equipe de Delfim). Um exame atento do seu conteúdo e um cotejo com declarações públicas de Delfim e assessores indicam convincentemente que foi elaborado pela Fazenda no início do governo Médici. A respeito, ver especialmente a entrevista de Delfim Netto à revista Mundo Econômico de janeiro de 1970.

15 Ver C. Viacava, “A modernização da agricultura brasileira", in Jornal do Brasil, 20/3/70. incentivador dos investimentos que é a ampliação do mercado", equacionando pois "o problema básico na formação do capital e no desenvolvimento". ${ }^{14}$

$\mathrm{Na}$ entrada dos anos 70, esse é "o único caminho que resta ao Brasil” para lograr "atingir as altas taxas de crescimento que almeja”. Com efeito:

Falecem alternativas para a estratégia proposta. As políticas utilizadas no passado, forçando a expansão com base no fator escasso, encontraram as limitações que trouxeram descontinuidade ao desenvolvimento.

As políticas utilizadas no passado dizem respeito ao conhecido conjunto de instrumentos acionados para dar apoio à industrialização por substituição de importação. A avaliação daquele processo é abertamente crítica, uma vez que acarretou "a redução da eficiência geral da economia" e "custos sociais maiores do que seria necessário com a utilização de uma política mais racional" - para colher um desenvolvimento que se revelou "de curta duração”. O importante, porém, é que

o processo de substituição de importações encontrou seu limite, e não se deve esperar dele a fonte dinâmica da aceleração do desenvolvimento industrial do país.

Qualquer tentativa de insistir com essa opção fracassaria em atingir "os objetivos mais importantes", quais sejam:
A ampla mobilização de recursos internos para a sustentação do desenvolvimento e o aumento geral da eficiência do sistema produtivo nacional.

Esse diagnóstico - originalmente desenvolvido no âmbito do pensamento cepalino - era partilhado pelo Planejamento e conduzia à formulação de uma estratégia "multissetorial" de desenvolvimento, incluindo como uma das fontes de dinamismo o aprofundamento da industrialização (vale dizer, para o Planejamento a substituição de importações não estava exaurida como tal, tão-somente como fonte única, exclusiva, do dinamismo). A estratégia de Delfim Netto é mais simples: o motor do processo provém da agricultura e das exportações; mais radical, ao sugerir uma rejeição integral das políticas do passado, oferecendo ao regime um modelo econômico "novo" que confirma a ruptura com a velha ordem pré-64; e, não menos importante, é dotada de forte apelo ao colocar a agricultura numa posição central (e ainda fazê-lo, afastando a incômoda proposta de reforma agrária). ${ }^{15}$

No "novo" modelo, a dinâmica do desenvolvimento ativada valendo-se de "um elemento exógeno" envolve tanto a agricultura quanto a indústria. Ocorre, porém, que as possibilidades de incremento das exportações industriais são reconhecidamente mais limitadas - e mesmo que isso não se verificasse, o seu efeito 
dinâmico seria reduzido, dada a participação "mínima" das exportações no total da demanda industrial. Daí a centralidade atribuída à agricultura. E dada a abundante disponibilidade de recursos ociosos e a existência de notável capacidade empresarial no setor, uma política econômica racional produziria o resultado esperado: "Sempre que incentivos adequados foram oferecidos ao setor, ele demonstrou uma ampla capacidade de resposta".

A resposta pretendida se traduziu nas seguintes projeções de crescimento: lavoura para o mercado interno $(6,8 \%$ a. a. $)$, pecuária para consumo interno $(9,0 \%$ a. a.), exportações (10,0\% a. a.), concluindo-se que "a demanda dos produtos de lavoura deve crescer em $7,9 \%$ a. a. e o da agricultura como um todo 8,2\%". ${ }^{16}$ Esse desempenho seria induzido pela adoção de "incentivos adequados" (redução de preços relativos), capazes de estimular a am- pliação do uso de fertilizantes e outros insumos e a mecanização, possibilitando uma expressiva elevação da produção por área e da área cultivada por pessoa. ${ }^{17}$

Embora a performance da agricultura seja explicitamente vinculada à questão da ampliação de mercado requerida pelo desejado crescimento acelerado, existe outra razão, em tese mais plausível, para o tratamento que lhe foi dispensado na nova estratégia. A experiência de desenvolvimento econômico do Brasil mostrava que as importações eram elásticas ao crescimento do produto, de forma que um adequado dinamismo das exportações era crucial para evitar que o crescimento acelerado fosse abortado pelo estrangulamento externo. Com efeito, a meta de crescimento das exportações agrícolas reflete precisamente o ritmo esperado de importações decorrente do crescimento do PIB a $9,0 \%$ a. a. ${ }^{18}$

\begin{tabular}{|c|c|}
\hline $\begin{array}{l}\text { Econômica do Governo: } 15 . \\
\text { Ver também o artigo citado } \\
\text { de Viacava. }\end{array}$ & $\begin{array}{l}10 \% \text { do seu preço real. } \\
\text { Ver também Delfim Netto, } \\
\text { entrevista a Mundo Econômico, } \\
\text { jan. } 1970 .\end{array}$ \\
\hline $\begin{array}{l}17 \text { Segundo o Programa, a } \\
\text { evidência de outros países } \\
\text { indicava ser muito alta a } \\
\text { elasticidade-preço do consumo } \\
\text { de fertilizantes; no caso do } \\
\text { trator, o documento apóia-se em } \\
\text { estimativas sinalizando um } \\
\text { aumento de } 16 \% \text { na sua } \\
\text { utilização para uma queda de }\end{array}$ & $\begin{array}{l}18 \text { Ver Delfim Netto, "É Preciso } \\
\text { Exportar Mais Para Acelerar o } \\
\text { Ritmo do Progresso", in Mundo } \\
\text { Econômico, set. } 1970 \text { - aí ele, } \\
\text { ironicamente, conclui: "E } \\
\text { aqueles que acreditaram ser } \\
\text { possível realizar o } \\
\text { desenvolvimento sem a } \\
\text { expansão das exportações }\end{array}$ \\
\hline
\end{tabular}

16 Programa da Política 10\% do seu preço real.

Econômica do Governo: 15.

Ver também o artigo citado

evidência de outros países indicava ser muito alta a

de fertilizantes; no caso do estimativas sinalizando um utilização para uma queda de

$\begin{array}{ll}\text { tiveram amargas desilusões ao } & \text { "O gargalo do desenvolvimento } \\ \text { verificar muito rapidamente que } & \text { brasileiro, na medida em que o } \\ \text { isso era impossível. Se nós } & \text { desejarmos, será a capacidade } \\ \text { tivéssemos tentado alcançar as } & \text { para importar". - "O } \\ \text { altas taxas de desenvolvimento } & \text { Desenvolvimento e o Comércio } \\ \text { sem simultaneamente nos } & \text { Exterior", in Revista de Finanças } \\ \text { termos preparado para agredir o } & \text { Públicas, ago. 1968. Ver também: } \\ \text { comércio exterior, teríamos } & \text { José Flávio Pécora, secretário- } \\ \text { caminhado para um tipo de } & \text { geral do Ministério da Fazenda, } \\ \text { endividamento que acabaria por } & \text { "Perspectivas das Exportações } \\ \text { inibir o próprio } & \text { Brasileiras", in Revista de Finanças } \\ \text { desenvolvimento". Em outra } & \text { Públicas, jan. 1970; Carlos } \\ \text { oportunidade Delfim advertira: } & \text { Viacava, artigo citado. }\end{array}$


19 Delfim Netto, em conferência no Instituto dos Advogados de Porto Alegre, esclareceria: "Algumas pessoas acreditam que esta ênfase extraordinária à agricultura representa uma diminuição da ênfase na indústria. É exatamente o oposto. A experiência dos anos 60 mostrou que não podíamos crescer a não ser com maior equilíbrio. Que não podíamos crescer deixando a agricultura retardada. Que não

poderíamos crescer sem criar um mercado interno para que essa indústria se debruçasse por todo o Brasil e se preparasse depois para invadir os outros mercados. A estratégia, portanto, quando dá grande força, grande vigor à política agrícola e à política de exportação é porque busca o equilíbrio dentro do desequilíbrio". -

"Desenvolvimento com liberdade", in O Estado de S. Paulo, 14/8/70.

20 Ver APEC, Carta Mensal: 12/11/69, p. 1 e 12/01/70, p. 2; Banas, 8/12/69, p. 13.
A retórica do modelo agrícola-exportador pode levar um observador desatento à conclusão de que a nova estratégia configurava um retrocesso, um retorno à época pré-industrial. Nada mais distante da realidade, porém. Sem dúvida representou um afastamento (no mínimo uma desconfiança pronunciada) de quaisquer teses pró-industrialização conforme cultivadas no Planejamento; ao mesmo tempo, a política econômica seria acionada para promover o crescimento da diversificada indústria já existente no País.

A expansão da agricultura e das exportações tinha justamente o papel de criar as condições para uma forte expansão industrial (a meta estabelecida inicialmente foi de 10,5\% a. a.). Como se antecipassem àquela possível objeção, os artífices da nova estratégia lembravam:

É necessário ressaltar que tal estratégia só é possivel porque o País dispõe, hoje, de uma estrutura industrial suficientemente ampla e diversificada. Não houvesse essa condição, a estratégia proposta poderia condusir a uma forte concentração da economia na agricultura. O estímulo às atividades agricolas na fase presente atuará como um dos elementos de dinamizaçãa da demanda interna de produtos manufaturados e, como tal, estimulará ainda mais o crescimento industrial (Programa: 12). ${ }^{19}$
Uma expansão industrial da ordem pretendida suscitava naturalmente $\mathrm{O}$ receio de se mostrar irrealista em face da magnitude dos investimentos requeridos. A aceleração dos investimentos era evidentemente uma pré-condição da sustentação do desenvolvimento mais rápido - e a estratégia desenhada identificava o caminho da ampliação de mercado capaz de induzir as decisões privadas de investimento. As ambições traçadas eram, sim, viáveis com base em uma análise mais próxima do mundo real: esta sugeria que o volume de investimento requerido, na verdade, não seria tão vultoso quanto o imaginado nas avaliações mais superficiais. Em primeiro lugar, reconhecia-se a existência de "margens bastante amplas" de capacidade ociosa na indústria, embora distribuída desigualmente entre os diferentes setores (a título de exemplo: a indústria automobilística e de autopeças experimenta acentuado desaquecimento no segundo semestre de 1969). ${ }^{20}$ Em segundo lugar, o estoque de capital herdado da industrialização por substituição de importações conferia, localizadamente, certa elasticidade à oferta, tendo em vista o excesso de capacidade criado em alguns setores. E o próprio conceito de capacidade é certamente flexível, predominando no Brasil o seu cálculo em ter- 
mos da utilização de um só turno de trabalho. Por tudo isso, estima-se viável a meta de expansão postulada:

Havendo possibilidades de parte do crescimento da produção (algo como 2 a 3\% ao ano) ser realizado pelo aproveitamento da capacidade hoje não utilizada, o crescimento necessário da capacidade produtiva será inferior à média dos últimos vinte anos, o que aumenta a convicção de que a expansão exigida poderá ser realizada (Programa: 20). ${ }^{21}$

E nesse sentido são arrolados alguns incentivos à "utilização intensiva da capacidade instalada":

a. redução dos encargos previdenciários e demais itens da legislação trabalhista nos acréscimos de turnos de trabalho;

b. diminuição dos encargos tributários sobre os acréscimos de produção provocados pelos turnos adicionais;

c. redução da tarifa para os consumos de energia elétrica industrial nos periodos noturnos, fora dos atuais picos de demanda;

d. aceleração da depreciação, vinculada à utiliz̧ação de turnos adicionais (Programa: 30-31)

A componente industrial da estratégia tinha também outra faceta, de natureza qualitativa. Tendo em vista que o processo de industrialização do pósguerra deixou como herança negativa uma estrutura caracterizada por baixo grau de eficiência, a busca de sua correção impunha-se como uma necessidade para o êxito da nova orientação decididamente voltada à integração na economia internacional. Postula-se, assim, uma mudança de perspectiva, de modo a reconhecer estar ultrapassada a fase de indústria nascente, devendo-se, pois, ingressar em uma nova fase "cuja característica básica deve necessariamente estar ligada à obtenção de níveis de eficiência iguais aos padrões internacionais". Isso implica uma política de importações "relativamente liberal", antecipando-se uma "cuidadosa redução tarifária" com o objetivo de intensificar a concorrência naqueles setores de maior ineficiência. E igualmente alguma margem para substituição de importações porventura ainda existente estaria sujeita à condição de se fazer "a níveis de eficiência internacional” (Programa: 20-21).

Um crescimento econômico como o pretendido exigiria certa taxa de poupança: esta é estimada em 20 a 22\% do produto, sendo 1,5 a 2\% a esperada contribuição da poupança externa (uma "insignificância”, razão pela qual não deveria "despertar temores ou animosidades" - mas, ainda assim, "um substancial auxílio, na margem"). A possível dificuldade para a sua mobilização decorria, sobretudo, da necessidade imperiosa de assegurar expressiva poupança pública para
21 A elasticidade da oferta refletiria também um sobredimensionamento de linhas ou seções das fábricas: ver a entrevista de Delfim Netto a Mundo Econômico, jan. 1970. José Flávio Pécora também chamaria a atenção sobre esse ponto: "Algumas vezes, com pequenos investimentos adicionais, pode-se operar mais intensamente conjuntos ou máquinas subutilizados que não estejam corretamente dimensionados com o restante das instalações fabris". -

"Perspectivas das Exportações Brasileiras", in Revista de Finanças Públicas, jan. 1970. 
$\cdots \cdots$

22 E num tom explicitamente crítico: "É com base em cálculos dessa natureza (utilizando uma relação produto/capital fixa) que freqüentemente se levantam objeções à possibilidade de crescimento mais rápido da economia. É claro que a objeção é inconsistente, uma vez que todos os estudos empíricos têm mostrado que a relação entre a taxa de crescimento do produto e taxa de formação de poupança é muito mais tênue do que se supunha." (Programa, p. 24).

23 Em discurso no Conselho para a América Latina, em Nova York, Delfim anunciou: "A retomada do ritmo de desenvolvimento, o virtual controle da inflação e a recomposição da situação externa deixam patente a melhoria verdadeiramente dramática das perspectivas econômicas do Brasil. O Governo do Presidente Médici lança-se agora num ousado programa de aceleração substancial da taxa de crescimento econômico ..."

- O Estado de S. Paulo,

9/12/69, e Revista de

Finanças Públicas, jan. 1970. viabilizar a expansão do investimento público (do contrário, este seria travado ou implicaria elevação da carga tributária, em ambos os casos desestimulando o investimento privado e frustrando as ambições de crescimento). Para tal, contava-se com a possibilidade de manter estáveis as despesas reais de custeio e as transferências: neste último caso, reconhecia-se que "certamente será um problema político importante" - mas tudo dependeria da "vontade política do governo".

Um último ponto merece ser destacado. A estratégia delfiniana se caracterizava por uma ousada aposta no crescimento, o que pareceria uma arriscada incursão voluntarista aos olhos dos planejadores mais cautelosos. Estes, porém, cometeriam um erro em seus exercícios de planejamento ao supor, incorretamente, uma relação produto-capital fixa. Essa suposição é negada pela evidência empírica, a qual mostra um comportamento que reforça a crença na viabilidade do crescimento acelerado:
A relação produto/capital tende a corre- lacionar-se positivamente com a taxa de crescimento do produto, o que significa que os países em rápida expansão encontram formas de aumentar a produtividade mé- dia do capital (Programa: 25). ${ }^{22}$

\section{3_A execução da política econômica: 1970-1973}

\section{1_A administração do "milagre": 1970-1971}

O objetivo de crescimento acelerado note-se, num ritmo jamais aventado até então pelo regime - desfruta de explícita primazia desde o início do governo Médici. A política econômica será intensamente acionada com esse propósito. A estabilidade dos preços, a primeira bandeira desfraldada em 1964 (e retomada com vigor logo após a edição do AI-5), é preservada como passagem retórica, eventualmente até como compromisso em 1972-1973, mas deixa de ser vista como a condição mesma do desenvolvimento mudando, pois, a hierarquia de prioridades da política econômica. A evolução da conjuntura o comprova, sem deixar margem para dúvida. ${ }^{23}$

O ano de 1970 iniciou-se trazendo sinais incômodos em matéria de inflação: de janeiro a março, enquanto o ICV acumulou alta de 4,4\% (contra 5,6\% em igual período de 1969), o IPA registrou forte aceleração, atingindo 5,5\% (oferta global - 2,5\% em 1969) e 4,7\% (disponibilidade interna $-2,3 \%$ em 1969). A perspectiva de manutenção do patamar infla- 
cionário suscitava inquietação em certos setores: volta e meia, pleitos em favor da adoção de um tratamento de choque seriam veiculados. Delfim os rejeitou sucessivas vezes ao longo do ano. ${ }^{24}$

Por vezes, a existência de um debate é revelada pelo próprio Delfim Netto - por exemplo, ao referir-se a uma "crise de fé" no gradualismo em curso, envolvendo "uma parcela da sociedade", um autêntico "frisson sobre a inflação". Delfim, escolhido "Homem de Visão de 1970", responde com indisfarçável rispidez. O tratamento de choque preconizado, tendo em vista o seu custo, não passa de uma "alegre irresponsabilidade", uma "aventura". Ainda mais porque totalmente desnecessário: a correção monetária, as minidesvalorizações cambiais e a liberação (sic) da taxa de juros constituem "mecanismos de compensação que eliminaram os efeitos da inflação antes de eliminar a inflação propriamente dita". O gradualismo é reafirmado com plena convicção:

Épor isso que nós estamos podendo crescere simultaneamente reduzir a inflação. Isso para alguns economistas parece impossivel, porque eles estão presos no esqueminha que está no livro. Dentro do esqueminha que está no livro não é possível mesmo.

Mas o fato é que "a realidade é um pouco mais rica do que a teoria", cabendo reconhecer que no Brasil "estamos diante de uma experiência nova" - capaz de "justificar, sob ângulo inteiramente diferente, a política gradualista". Esta, convém lembrar, "não significa que se considere menos importante a eliminação do processo inflacionário"; mas, decididamente, "significa que quando temos de trocar menos $5 \%$ de inflação com mais $2 \%$ de produto, ficamos com o produto". ${ }^{25}$
24 A favor do choque: APEC, Carta Mensal, 12/4/70

(Apêndice) e 12/5/70, p. 4; editorial de $O$ Estado de $S$.

Paulo, 15/1/70; artigos de Campos e Simonsen no Jornal do Brasil, 20/3/70. Mensagens de Delfim Netto: "Não se deve esperar que a política de combate à inflação, no estágio em que se encontra, provoque uma redução na produção industrial. [...] nossa expectativa é que ocorra exatamente o contrário, uma vez que agora as pressões de demanda são relativamente menores do que as pressões de custo". - Banas, 1/6/70. p. 11. "Não temos o menor interesse de impor um tratamento de choque à sociedade brasileira. Não precisamos [...] de uma política mais violenta, no momento em que o setor privado retomou sua confiança
[...] Todavia, não sei quando a inflação será debelada, pois ela não depende do Ministro da Fazenda [...] Ela depende de todos nós". - depoimento no Senado, in Jornal da Tarde, 17/7/70. No início do ano, Delfim havia acenado com um gradualismo efetivo, sugerindo uma redução da inflação para um nível inferior a $18 \%$ - ver Revista de Finanças Públicas, fev. 1970, p. 42. 25 As citações foram extraídas livremente dos artigos "A alegria da irresponsabilidade", in Jornal da Tarde, 15/10/70; "Experiência nova no Brasil", in Economia Paulista, dez. 1970; e do seu discurso reproduzido in Visão, 7/11/70. Ver também a nota de apoio "total, completo e irrestrito" à política delfiniana por parte da ADECIF, in APEC, Carta Mensal, 15/11/70, p. 18. 
$\ldots \ldots \ldots \ldots$ 26 Visão, 29/3/71, p. 96 e 100. Ver também o artigo de Delfim no Jornal da Tarde, 15/10/70.
O gradualismo da política econômica do "milagre" tinha interessante implicação, merecedora de registro. A opção pela convivência com uma inflação sob controle, neutralizada em seus efeitos, indicava a preservação indefinida da correção monetária, originalmente instituída com caráter provisório. Um culto às virtudes da correção monetária ganharia força durante esses anos. Delfim Netto referir-se-ia a ela como um "extraordinário instrumento, agora objeto da burrice nacional"; e daria o seu veredicto:

Como todo instrumento, tem seus lados positivos e negativos. Deve ser julgado do ponto de vista da soma algébrica; deste ponto de vista, considero o resultado positivo.

Reis Velloso seria mais explícito:

Nunca devemos abrir mão do princípio da correção monetária, o que não quer dizer que o sistema não possa sofrer algumas reformas. [...] Poderíamos aplicar um fator de correção da correção monetária; por exemplo, estabelecer que somente 90 a $95 \%$ da correção seja aplicada. ${ }^{26}$

A marca distintiva da política monetária durante o "milagre" foi o seu caráter expansionista. Os pleitos pró-choque pretendiam reverter esse comportamento; a defesa do gradualismo sintetizava a recusa em implementar qualquer restrição de liquidez que pudesse comprometer o ritmo de crescimento almejado. Contudo, pelo menos em 1970, a sua execução refletiu certa cautela: a expansão real da oferta de moeda não passou de $6 \%$, de longe o desempenho mais modesto observado de 1967 a 1973. Mas convém não perder de vista o seguinte:

1. ela foi razoavelmente bem dosada ao longo do ano (contrastando com a experiência de 1969);

2. nota-se um uso intenso dos mecanismos de crédito seletivo;

3. sobretudo, a política fiscal foi manipulada com desenvoltura, visando deliberadamente ampliar a disponibilidade de liquidez para as empresas.

Vejamos as medidas mais significativas nessa área, todas da primeira metade do governo Médici.

\subsection{1_Política monetária: crédito e juro}

A Resolução 130, de 27/1/70, reduziu de $27 \%$ para $25 \%$ o depósito compulsório, criando uma faixa especial de financiamento destinada a pequenas e médias empresas. Para desfrutarem dessa redução, os bancos deveriam completar com um terço de recursos próprios o volume de financiamento previsto. A taxa de juros foi fixada em 1,5\% a. m., e o prazo da 
operação, em doze meses; dado o seu caráter permanente, a faixa especial abria a possibilidade de rotação dos créditos. ${ }^{27}$

A Resolução 134, de 18/2/70, reduziu em $0,2 \%$ a. m. as taxas de juros dos bancos comerciais, agora fixadas em $1,6 \%$ a. m. nas operações até 60 dias e $1,8 \%$ a. m. nas de prazo superior. Outra Resolução, de $n^{\circ} 136$, estabeleceu um redutor de $10 \%$ sobre as taxas cobradas pelos bancos de investimento em suas operações ativas. Já as financeiras foram poupadas, beneficiadas pela redução de 3\% para $2 \%$ da taxa de colocação das letras de câmbio (Resolução 137).

Essas medidas certamente perseguiam o objetivo de melhoria das condições de crédito - não há por que duvidar da intenção manifesta da política econômica de trazer as taxas de juros reais para níveis que "não ultrapassem 8 a 10\% ao ano". ${ }^{28}$ Mas não deve passar despercebido que os grandes bancos já praticavam a taxa de 1,6\% a. m. (desde a Resolução 114, de 1969) - e agora seriam compensados com alguns benefícios adicionais, a saber: elevação de 50 para 55\% da parcela remunerada em ORTN do compulsório, liberação da taxa de juros nas operações de crédito pessoal (até então fixadas em 2,2\% a. m.), bem como eliminação de restrições quanto a prazos (vista como uma abertura para a sua entrada no CDC). É possível que apenas os bancos médios e pequenos, e os bancos de investimento, tivessem de ajustar seus custos para enfrentar o cenário de taxas de juros mais baixas - indiretamente, as decisões do BC favoreciam o movimento de concentração bancária e centralização financeira, sabidamente políticas promovidas con amore no período.

\subsection{2_ Política fiscal: financiamento do capital de giro a custo zero}

A prática, observada anteriormente em caráter emergencial, de dilatação dos prazos de recolhimento dos impostos indiretos, torna-se permanente a partir de 1970 , contribuindo para a expansão do ritmo de atividade numa medida difícil de quantificar, mas cuja importância não deve ser subestimada. Esse instrumento foi manipulado com alguma seletividade, concedendo prazos máximos para setores debilitados ou prioritários (tal foi o caso da indústria têxtil, aquinhoada com um prazo de 75 dias em jan./70, ampliado para 120 dias no final de maio - quando passou a beneficiar também as indústrias de calçados e aço). Para a maioria dos setores industriais, concedeu-se um prazo de 60 dias (jan./70), ampliado sucessivamente para 75 dias (maio/70) e, por fim, 90 dias $\cdots \cdots$

Ver a nota do Ministério da Fazenda e declarações de Delfim: "É óbvio que a taxa de juros global nunca poderá ser negativa, mas a setorial, correspondente aos objetivos do Governo, pode e deve ser negativa ...", in Revista de Finanças Públicas, fev. 1970 , p. 41-43. Ver também “A ajuda demorada", in Veja, 11/2/70, p. 41-42.

28 Ver a entrevista de Delfim a Mundo Econômico, jan. 1970, p. 28. Também suas declarações "Capital de giro e sistema bancário", in Revista de Finanças Públicas, fev. 1970, p. 2. As taxas de juros cobradas pelas financeiras e bancos de investimento estariam em torno de 37 a $44 \%$ a.a. (Visão, $28 / 2 / 70$, p. 43). 
(fev./71). Alguns setores foram excluídos do benefício, destacando-se os casos de bebidas, cigarros e veículos.

Com menor abrangência e profundidade, também o ICM do setor industrial teve seus prazos de recolhimento alongados. O convênio do Rio de Janeiro, de 15/1/70, reunindo os secretários estaduais da Fazenda, estipulou um cronograma com esse objetivo. Logo em seguida, o Decreto n. 52.389, de 16 de fevereiro de 1970, e o Decreto n. 52.462, de 6 de junho de 1970, tornaram compulsórios aqueles prazos dilatados para vários setores (por exemplo: siderurgia, têxtil e calçados). Pelo menos São Paulo efetivamente concedeu prazos maiores para o

\begin{tabular}{|c|c|}
\hline Delfim Netto explica o & taxa de juro zero, que o \\
\hline sentido dessas medidas: & Estado entregou a essas \\
\hline "Hoje, o IPI, todo ele, é & empresas. [...] São medidas \\
\hline recolhido a prazos maiores & que estão procurando \\
\hline que os prazos médios de & controlar, no prazo mais \\
\hline venda dos setores. Isto é, & longo, a taxa de juros". - \\
\hline nenhuma indústria, ninguém, & Banas, 16/8/71, p. 8 \\
\hline em princípio, financia mais o & 30 As citações são das páginas \\
\hline IPI. O mesmo está & 5 e 6. A revista $V_{e j a}$, de \\
\hline acontecendo com o ICM. Isso & $14 / 1 / 70$, noticia o debate no \\
\hline representa uma redução da & interior do regime acerca \\
\hline busca de capital de giro das & dessa questão e o \\
\hline empresas nos bancos e & compromisso de Médici em \\
\hline significa, portanto, uma & dar uma resposta em breve. \\
\hline dução do custo do dinheiro & Ver também declarações de \\
\hline Ira as empresas. É recurso, a & Velloso, in Visão, 28/2/70. \\
\hline
\end{tabular}

recolhimento do ICM já em 1970 e novamente em 1971 (em alguns casos, o prazo fixado chegou a 60 dias). ${ }^{29}$

\subsubsection{Os fundos PIS/PASEP e a melhoria das condições de crédito}

Em 1970, são instituídos os fundos PIS/ PASEP, refletindo a preocupação oficial com a injusta distribuição de renda. As Metas e Bases para a Ação do Governo identificariam aí um dos "grandes problemas éticos do nosso tempo" - mas explicitamente descartavam qualquer "excesso redistributivista que sacrifique a aceleração da taxa de crescimento nacional". ${ }^{30} \mathrm{O}$ Programa de Integração Social foi concebido nesse espírito. É importante observar como foi a sua operacionalização.

Em simultâneo à criação do PIS, uma resolução do Senado Federal (n. 65, de 19/8/70) reduziu as alíquotas de IPI e ICM em 0,5\% a. a., de 1971 a $1974 . \mathrm{Na}$ avaliação de Reis Velloso, o fundo seria, assim, inteiramente financiado via redução da carga tributária - e ainda propiciaria um bônus (a redução gradual do IPI) na forma de ampliação do capital de giro próprio das empresas. E o próprio mecanismo de recolhimento - defasado de 6 meses - representou disponibilidade de financiamento do capital de giro a custo zero para o setor empresarial que não há que se desprezar. Finalmente, a mobiliza- 
ção desses fundos pela CEF representou óbvia ampliação da oferta de crédito. ${ }^{31}$

\subsection{4_ Mudanças operacionais na política monetária}

O ano de 1970 é o da implantação do open market (após uma fase experimental em 1968-1969 utilizando a ORTN com prazo decorrido): o quadro institucional ganhou forma no Decreto-Lei n. 1079, de 29 de janeiro de 1970, e na Resolução n. 150, de 22 de julho de 1970 . Esse aperfeiçoamento da política monetária, coroando os movimentos anteriores de redução do desequilíbrio fiscal e a introdução das minidesvalorizações cambiais (ambos pré-condições para a eficácia da política monetária), teve outras implicações não menos importantes.

$\mathrm{O}$ open facultaria aos bancos remunerar parte do seu encaixe, desenvolver as operações interbancárias (negadas legalmente, mas cedo institucionalizadas pela sistemática do “cheque BB”) e projetaria possíveis passos futuros (por exemplo, redução dos depósitos compulsórios, tornados um instrumento antiquado) visando à redução de custos operacionais. ${ }^{32}$ E naturalmente o open constituiria uma esfera de valorização dos capitais em aplicações de curto prazo, numa conjuntura de alongamento de prazos de recolhimento e redução/isenção de impostos, etc. Interessante notar que, já no ato de nascimento do open, observaram-se algumas deformações reveladoras da sua potencialidade "para o mal" (carta de recompra, fracionamento dos títulos de elevado valor, visando atrair o "pequeno poupador"), obrigando o Banco Central a intervir - é o caso, por exemplo, da Cir-

\section{Delfim Netto vincularia o}

PIS ao objetivo permanente

de redução das taxas de juros, pré-condição do crescimento: "Na medida em que o fundo vai servir como captação de recursos que se transformará em capital de giro das empresas, ele reduzirá a demanda de capital de financiamento por parte dessas empresas e certamente vai baixar a taxa de juros. $\mathrm{O}$ mesmo efeito se obteve quando se ampliou e continua a se ampliar o prazo do recolhimento dos impostos. De forma que tudo está caminhando para baixar a taxa de juros. Os empresários financeiros têm de compreender que essa é uma necessidade imperiosa e as taxas de juros vão ter de baixar neste país de qualquer forma. O fundo será apenas mais um instrumento para a realização deste objetivo" Revista de Finanças Públicas, ago. 1970 , p. 2-16. Para um exame detalhado do PIS, ver Loloian, 1980 (a citação de Velloso encontra-se na p. 22).

32 Isso foi indicado por Delfim Netto: “As operações de mercado aberto são o substituto eficaz para o velho sistema de taxas mínimas ou obrigatórias de depósitos compulsórios. Estamos aprendendo a trabalhar com o open market para poder superar aquele sistema, extremamente oneroso para os bancos. [...] Vai ser um instrumento $\ldots \ldots \ldots$ extremamente importante no futuro para controle da liquidez global do sistema econômico brasileiro. E vai ajudar a reduzir muito os empréstimos compulsórios, quando chegar o momento apropriado. Portanto, vai ser uma operação que reduzirá de maneira substancial o custo do sistema bancário." - Visão, 7/11/70, p. 36-38. 
cular 145, de 25/9/70, que buscou coibir a prática do fracionamento. ${ }^{33}$

A mudança na sistemática da política monetária seria completada pelas Resoluções n. 168 e n. 169, de 22 de janeiro de 1971: a primeira simplificou o redesconto de liquidez, convertido em "assistência financeira" do BC, consistindo em abertura de crédito por prazo indeterminado e o controle sendo exercido via manipulação dos limites, prazos de utilização e taxa de juros; a segunda introduziu a média quinzenal dos depósitos, no lugar de um dia determinado, como base de cálculo dos recolhimentos compulsórios devidos pelos bancos comerciais.

\subsection{5_Incentivos às exportações de manufaturados}

Como se sabe, desde 1964, a política fiscal vinha sendo acionada num crescendo visando à promoção de exportações. Duas medidas merecem destaque. O crédito prêmio de IPI, introduzido em 1969, foi habilmente manipulado nos anos seguintes: por exemplo, a Portaria GB-14, de 15 de janeiro de 1970, estabeleceu a possibilidade de transferência para terceiros, como pagamento de matérias-primas, embalagens, etc., do eventual excedente de créditos (sendo facultado aos fornecedores utilizar tais créditos para abater o seu IPI devido); e uma sucessão de portarias fixariam alíquotas especiais de IPI, válidas apenas para cálculo do crédito fiscal (em alguns casos, alcançando o dobro, ou mesmo o triplo, da alíquota válida para o mercado interno). Em 15 de janeiro de 1970, o Convênio do Rio de Janeiro estabeleceu um mecanismo de crédito prêmio do ICM, semelhante ao IPI. ${ }^{34}$

\subsection{6_ Apoio "estratégico" à agricultura: incentivos à elevação de produtividade}

O governo Médici elegeu a agricultura sua prioridade. A retórica da política econômica identificará 1970 ao “ano da agri-
33 Ver matéria do Jornal da

Tarde, 20/10/70, informando que um grande banco paulista vinha operando com garantia de recompra. Ver também de R. Appy, "Open market ainda não deslanchou”, in Economia Paulista, set./out. 1970.

34 Essa política adquiriu tal enraizamento que, em 1972, durante uma exortação aos exportadores, Delfim se atreveu a proclamar: "[...] não creio que ninguém possa alterar esse processo de incentivos que foi criado. Não há a menor possibilidade que isto seja mudado no futuro visível, de forma que os senhores podem tratar de fazer seus investimentos para a exportação com a maior tranqüilidade. Não há força material capaz de mudar esta orientação do governo". Nem mesmo o risco de retaliações seria capaz de fazer recuar essa política, pois “ $[\ldots]$ no dia em que objetarem, já temos um sistema alternativo pronto. As contribuições (como Fundo de Garantia, Funrural, etc.) pesam em $76 \%$ sobre a folha salarial. Transformam-se essas contribuições em impostos sobre vendas ou em
IPI Assim, no momento em que apresentassem objeções ao mecanismo de créditos, se poderia dobrar o valor do IPI, recolher o IPI, devolver ao INPS a sua parte e dar como crédito de IPI a diferença.

Ficaria tudo na mesma, mas as regras estariam satisfeitas." Visão, 28/8/72, p. 424. 
cultura", tal o tratamento a ela dispensado. A retórica justifica-se, tendo em vista o conjunto de incentivos dados ao setor. Incentivos esses visando à ampliação da mecanização e do uso de insumos modernos, consolidando a sua transformação em agronegócio.

Assim, cabe destacar:

1. isenção de IPI e de ICM sobre tratores e demais máquinas agrícolas;

2. isenção de ICM sobre os insumos utilizados na produção de adubos e fertilizantes;

3. incentivo fiscal à compra de tratores e máquinas agrícolas, fertilizantes, defensivos, etc. (tratados como investimentos, permitindo abater até $80 \%$ do rendimento líquido sujeito ao IR);

4. redução do IR devido pela agricultura (limitando o rendimento tributável a 10\% em 1970 e $25 \%$ em 1971 do rendimento líquido após a dedução dos investimentos realizados);

5. isenção de IPI sobre matérias-primas, produtos intermediários e material de embalagem utilizados pela indústria de máquinas e implementos agrícolas;

6. isenção de ICM sobre motores e engrenagens utilizados na fabricação de tratores. ${ }^{35}$
A isso tudo some-se a farta disponibilidade de crédito, a juros favorecidos. $\mathrm{O}$ volume de financiamento de tratores, em termos reais, realizado pelo Banco do Brasil a uma taxa de juros fixa em 15\% a. a., após sofrer uma retração em 1969, cresce 16,5\% em 1970 e, em seguida, praticamente triplica até 1973 . O volume de crédito para fertilizantes, em termos reais, após sofrer retração em 1969, cresce acima de 150\% em 1970 e acima de 200\% em 1971: em 1973, alcançando um valor 4,5 vezes maior que o de 1970 , já representava $14 \%$ do volume total do crédito rural (em 1969 apenas 3,6\%). Note-se que, pelo Fundag, a taxa de juros nessa modalidade permaneceu fixa em $7 \%$ a. a. E o crédito rural total, por sua vez, cresce 18,8\%, em termos reais, em 1970, e simplesmente dobra até 1973.36

A sua política econômica foi uma vez descrita por Delfim Netto como uma "política de libertação do empresário": ao libertá-lo, o governo tornava viável o desenvolvimento com base na agricultura e nas exportações.
A resposta da agricultura aos estimulos é o que se pode dizer uma experiência crítica, é a resposta definitiva àqueles que acredita- vam que o sistema era incapaz de atender aos estímulos do lucro. Nós temos uma coi- sa extremamente rara e que talvez nos dis- tinga de todo o mundo subdesenvolvido: o fator mais escasso que é o empresário.

35 Essa última medida é de abril/71 e propiciaria nova redução no preço final do trator, estimada em 3 a 4\% ver Exame, set. 1971, p. 212. As demais datam do primeiro ano do governo Médici.

Referências a essas diferentes medidas localizam-se em Revista de Finanças Públicas, jan. 1970 , p. 40; fev. 1970 , p. 45 e 47; jul. 1970 , p. 50; out. 1970 , p. 47. Ver também o telegrama (de “júbilo”) enviado ao presidente e seus ministros pela Federação da Agricultura do Estado de São Paulo, in O Estado de S. Paulo, 24/1/70.

36 Barros (1980):127; IPT (1981):II-60. 
$\ldots \ldots \ldots$

37 Entrevista coletiva na recém-formada Associação dos Jornalistas de Economia e Finanças, in Revista de Finanças Públicas, fev. 1970, p. 43 e mar. 1970 , p. 3. Na linha do modelo agrícola-exportador, ele diria então: "Uma expansão da renda agrícola, como a que vai se verificar neste ano, tende a produzir uma expansão extraordinária da demanda de bens industriais. Estão, portanto, criadas as condições necessárias para a realização do desenvolvimento".

38 Visão, 7/11/70. Ele reafirmaria essa expectativa em entrevista à revista Progresso, mar./abr. 1971.

39 Os números são extraídos de "Agricultura num contexto de recessão", Paulo Rabello de Castro e Renato Ticoulat Filho, in O Estado de S. Paulo, $27 / 12 / 81$.

40 Para um exame pormenorizado, ver CEFER-IPT (1980); os dados da indústria de tratores são de Barros (1980) e Banas, 10/9/73.
Com efeito, no início de 1970, Delfim antecipava que "a produção agrícola baterá todos os recordes". ${ }^{37} \mathrm{O}$ mau desempenho da cultura de café frustrou essa previsão, mas não abalou a certeza da futura resposta do empresariado agrícola. No final do ano, Delfim reafirmaria sua crença:

\section{Desde a posse do Presidente foi tomada uma série de medidas, todas na direção da expansão da produtividade da agricultu- ra. Acho que abril ou maio de 1971 vai revelar que esse esforço extraordinário ob- teve uma resposta espantosa do setor agrí- cola brasileiro. Não tenho dúvidas de que 1971 deve revelar a maior taxa de cresci- mento da agricultura de que se tem noticia na história deste pais. ${ }^{38}$}

De fato, a agropecuária cresceu $11,4 \%$ em 1971 (e a lavoura cerca de 14,8\%) - espetacular, sem dúvida, porém uma performance que não se repetiria nem em 1972 (4,1\%), nem em 1973 (3,5\%). Não obstante, o auge cíclico prosseguiu vigorosamente; como explicá-lo a partir da "estratégia agrícola-exportadora"? 39

Mas é certo que essa política impulsionou com força a indústria de tratores, a qual operava com $50 \%$ de capacidade ociosa em 1969; a expansão da produção alcança sucessivamente marcas impressionantes: 47\% em 1970, 57\% em 1971, $32 \%$ em 1972, induzindo um estado eu- fórico das expectativas. Com isso, o setor, estagnado desde a conclusão de seu primeiro ciclo de investimentos em 1962, voltaria a investir, duplicando a capacidade instalada durante o "milagre". No caso dos fertilizantes, a produção de nitrogenados cresce aos saltos, multiplicando-se por oito entre 1970 e 1974 (5,5 entre 1970 e 1973), enquanto a de fosfatados cresce acima de $150 \%$ no período (praticamente duplica de 1970 a 1973). Em ambos os tipos, contudo, o peso das importações era superior a $50 \%$ do consumo - já os potássicos eram importados na sua totalidade; assim, no período observam-se taxas elevadíssimas de crescimento das importações (à exceção de 1973, quando a conjuntura agitada vivida pelo mercado afetou as importações). ${ }^{40}$

\subsection{7_Política industrial: Plano Siderúrgico Nacional, incentivos ao investimento e à indústria de bens de capital}

A aceleração do crescimento tornaria evidente o atraso na expansão de capacidade da siderurgia. O setor fora prejudicado não só pela desaceleração industrial pós-1962, mas também por fatores vários, como preços contidos que afetavam a capacidade de autofinanciamento (sobretudo durante o PAEG); redução de tarifas de importação em 1966, e, novamente em 1967, projeções pessimistas da necessidade futura de aço (relatório 
Booz-Allen). Dessa forma, até o governo Médici não tivera início qualquer programa de investimento antecipando um possível ponto de estrangulamento futuro. Com isso, acompanhando o crescimento acelerado, as importações de aço em relação ao consumo aparente ingressariam em uma trajetória ameaçadora: 12,4\% em 1969, 14,5\% em 1970, 21,9\% em 1971. O Plano Siderúrgico Nacional tornava-se, então, inadiável - e veio inteiramente permeado do clima Brasil Grande Potência, característico do período, ao fixar, em dez./70, a meta de quadruplicar a produção de aço em uma década, a qual deveria alcançar 20 milhões de toneladas em 1980.41

Por outro lado, a continuidade do crescimento acelerado dependia evidentemente da concretização das decisões de investimento do setor privado. $\mathrm{O}$ crescimento do investimento público e do setor produtivo estatal - a taxas anuais de 12,2 e
27,7\%, respectivamente, em 1970-1973 sem dúvida teve grande importância, dado o seu efeito indutor sobre as decisões privadas. Mas não deve ser negligenciado o papel da política econômica, cultivando um otimismo sem restrições (como se pretendesse atiçar o animal spirits do empresariado) e, sobretudo, distribuindo incentivos (no fundo, respostas às solicitações da indústria). Por exemplo, Reis Velloso demandaria dos empresários uma atitude mais arrojada, fazendo hoje o que talvez pensassem fazer apenas amanhã:

\section{[...] numa prova de confiança em si mes- ma e na Nação, deve a indústria fazer agora os investimentos e proceder à am- pliação de instalações que pretenderia fa- zer daqui a um, dois ou três anos. Ante- cipar os investimentos é uma necessidade básica para o Brasil. 42}

Os incentivos seriam ampliados e, sobretudo, eliminariam a discrimi-

\footnotetext{
41 Segundo Pratini de Moraes, Segurança e Desenvolvimento

da Indústria e Comércio: "Se a produção siderúrgica fosse mantida nos níveis atuais $-5,4$ milhões de toneladas anuais -, em poucos anos o processo de desenvolvimento poderia ser comprometido, pela nossa crescente dependência das importações". - "A Siderurgia e o Desenvolvimento”, in

n. $154,1973$.

42 Pronunciamento no

banquete anual da indústria elétrica e eletrônica: "Governo só apoiará indústria eficiente", O Estado de S. Paulo,

12/12/70. Velloso renovaria a exortação em entrevista ao Correio da Manbã, 25/1/71.

Delfim, por sua vez, quando

dissertava sobre a "libertação do empresário" promovida pela política econômica, tinha presente que o desenvolvimento "é mais uma questão de mobilização”, “é basicamente obra do setor privado" - não poupando esforços, pois, para promover o seu engajamento, a sua "crença" (ele diria mesmo: "Precisamos acreditar que o desenvolvimento é possível”). Ver suas declarações na Associação dos Jornalistas de Economia e Finanças, in Revista de Finanças Públicas, fev. 1970, p. 43. Para uma análise do investimento do setor público, ver Dain (1979).
} 


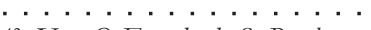

43 Ver O Estado de S. Paulo, 23/1/71. Na CNI, Delfim comentara que a nova política industrial "será um passo decisivo para que nos tornemos uma grande potência industrial"; "o ano de 1971 está destinado a tornar-se o grande ano da indústria de base" - Revista de Finanças Públicas, nov. 1970, p. 44-45. O otimismo de Delfim era, na verdade, ainda maior, vaticinando: “ [...] lograremos fomentar o último setor que faltava amparar dentro da economia brasileira: o das máquinas que produzem máquinas. Com isso, a economia brasileira adquirirá um nível de maturidade insuspeitada nos últimos anos. Estaremos realmente em condições de alcançar um grau de desenvolvimento acelerado e auto-suficiente." - entrevista à revista Progresso, mar./abr. 1971. Para exemplos da posição da indústria acerca do crédito de longo prazo, ver, por exemplo, as entrevistas de Estevam Faraone, da Romi, in Banas 13/4/70; e Manoel da Costa Santos, da ABINEE, in Banas, 24/8/70. nação diante das importações até então sofrida pela indústria nacional de bens de capital - através dos Decretos-Leis n. 1.136 e n. 1.137, Decreto n. 67.707 e Portaria GB-334, todos de 7 de dezembro de 1970, estabelecendo: isenção do imposto de importação, do IPI e do ICM, quando da importação de equipamentos, máquinas, aparelhos e instrumentos, acessórios e ferramentas, sem similar nacional, bem como de partes complementares à produção nacional; crédito do IPI ao comprador de equipamento nacional; depreciação acelerada sobre os bens de fabricação nacional, para efeito de apuração do imposto de renda. E o Convênio do Rio de Janeiro, de 12 de janeiro de 1971, concederia também a isenção de ICM à indústria de bens de capital; no caso de São Paulo, essa decisão foi imediatamente ratificada através do Decreto estadual n. 52.656, de 15 de janeiro de 1971. Por fim, via BNDE-Finame e CEF-BB (mobilizando os fundos PIS/PASEP), seria ofertado o indispensável crédito de longo prazo, condição essencial da competitividade da indústria de bens de capital (e uma antiga reivindicação). Não sem razão, Delfim comunicaria à FIESP: “Terminada a execução do programa destinado à agricultura, o governo iniciou a formulação do ano da indústria". 43

\subsection{A conjuntura 1972-1973 \\ e as contradições da política econômica do "milagre"}

A política econômica parece ter desfrutado ao longo de 1970-1971 uma "lua de mel" prolongada: distribuição generosa de incentivos (à agricultura, aos exportadores, à indústria, aos bancos); colheita farta de crescimento econômico (incluindo, em 1971, a longamente aguardada supersafra agrícola), inflação estabilizada, aumento progressivo das reservas internacionais - nem mesmo o fiasco que acometeu a Bolsa de Valores em 1971 foi capaz de empanar o brilho da administração econômico-financeira. Em 1972-1973, combinam-se uma conjuntura econômica internacional e doméstica de intenso crescimento, geradora de dificuldades para a condução da política econômica; esta, ademais, explicita em sua formulação ambições que aprofundam as dificuldades. É conveniente, pois, tratar em separado esse subperíodo, considerando-o uma nova fase (terminal) da política econômica do "milagre" - na medida em que se verificou a sobreposição de algumas condicionantes novas.

Em primeiro lugar, há que se ter presente os efeitos do boom sincronizado das economias capitalistas desenvolvidas, observado nesses anos. O início da década fora marcado pela recessão nor- 
te-americana, enquanto as demais economias desenvolvidas apresentavam comportamentos diferenciados (Japão, França e Alemanha mantiveram um elevado crescimento; Canadá, Reino Unido e Itália exibiram, quando muito, crescimento rastejante). A recuperação dos EUA teve início durante 1971, evoluindo para taxas reais de crescimento do PNB da ordem de 5,7\% em 1972 e 5,5\% em 1973 (o crescimento mais vigoroso desde 1966). As demais economias desenvolvidas também cresceram e a taxas ainda maiores até mesmo o Reino Unido conseguiu, em 1973, sair do seu crônico estado de crescimento rastejante, exibindo taxa de crescimento próxima de 6\%. Um determinante chave dessa conjuntura foi o manejo da política monetária pelo FED, caracterizado por incomum flexibilidade (oferta abundante de liquidez e baixas taxas de juros). A repercussão se fez em várias direções: o comércio mundial atingiu os maiores índices de expansão de todo o pós-guerra; o mercado de euromoedas, que vinha há anos em uma trajetória vertiginosa, simplesmente duplica entre 1971 e 1973, tornando clara a conjuntura de sobreliquidez internacional; e os preços internacionais dos produtos primários desfrutaram entre 1972 e 1974 o seu maior boom desde o pós-guerra, superior mesmo ao ocorrido durante a Guerra da Co- réia no início dos anos 50. Este último ponto merece ser destacado. O boom sincronizado do capitalismo avançado intensificou a demanda mundial por alimentos e matérias-primas industriais (um mercado caracterizado pela dominância de preços flex), tendência reforçada por movimentos especulativos desatados pela alta de preços num ambiente de juros reduzidos. Com efeito, os preços dos alimentos crescem 54,0\% em 1972 e 43,2\% em 1973 , enquanto os preços das matériasprimas industriais exibem alta de 29,4\% em 1972 e 74,2\% em 1973. ${ }^{44}$

No plano interno, o crescimento a altas taxas, prolongando-se por vários anos, terminou desaguando numa conjuntura de superaquecimento, com os níveis de produção tendendo a esbarrar no teto da plena utilização de capacidade. O ritmo acelerado dos investimentos, característico do auge, contribuiu para manter em contínuo crescimento a demanda, excitando as expectativas empresariais, o que culminará em sobreinvestimento - assim, ao longo do tempo, o processo tende a desdobrar-se em uma crise de superacumulação de capital (isso já ocorrera na crise dos anos 60 e voltaria a repetir-se na crise do "milagre").

Mas, a curto prazo, dada a defasagem entre os gastos de investimento e a resultante expansão de capacidade, o que

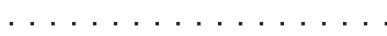

44 Os dados se referem a jan./72, jan./73 e jan./73, jan./74. Ver a análise de A. Udry, in Mandel (1977). 
45 Acerca dos dados da Sondagem Conjuntural da FGV, ver a análise de Bacha (1976). eventualmente pode observar-se no pico do auge cíclico são manifestações variadas e mais ou menos intensas de escassez - de matérias-primas, de insumos, de mãode-obra. Isso é tão mais certo quanto a política econômica pratique uma orientação expansionista sem vacilações, sempre alardeando estar na retaguarda do empresariado, com o objetivo renovado ano a ano de crescer a altas taxas, assim impulsionando um otimismo irrefreável no estado das expectativas. $\mathrm{E}$ ainda mais se a atividade de planejamento é atropelada pelo poder de sedução do pragmatismo centrado nas possibilidades do presente - ou, no mínimo, entra em operação tardiamente.

São conhecidos os indicadores que apontam para a plena utilização de capacidade em quase toda a indústria de transformação no biênio 1972-1973. Um dado bastante sugestivo da febril conjuntura vivida pela economia reside na proporção de indústrias considerando o nível de demanda como "forte", ao invés de "normal" ou "fraca", obtido pelas sondagens conjunturais da FGV, um índice aproximado do estado d'alma imperante no mundo empresarial: aquela proporção aumenta vigorosamente após abr./72, alcançando percentual recorde no final do ano $(0,31$ - superior ao maior valor registrado desde 1968, equivalente a 0,27), para seguir crescendo intensamente ao longo de 1973, quando registraria marcas dificilmente igualáveis $(0,49$ em julho e 0,60 em outubro). ${ }^{45}$

Dessa forma, especialmente no ano de 1973, foram freqüentes as queixas de dificuldades setoriais decorrentes da escassez de matérias-primas e insumos (às vezes originando-se no mercado internacional, como exemplificado pelo caso dos fertilizantes). Ao disseminar-se a percepção de escassez, tem início um movimento especulativo (antecipação de compras), contribuindo para intensificar a escassez (e a correspondente pressão localizada sobre os preços). $\mathrm{Na}$ indústria automobilística, as montadoras se defrontaram com limitações físicas no suprimento de chapas de aço; as firmas de autopeças foram afetadas pela falta generalizada de aço, registrando-se casos de paralisação total da linha de produção (além, é claro, de queixas insistentes de forte elevação dos custos, não reconhecida pelo CIP v.g., disseminava-se no mercado a prática de sobrepreço). A indústria têxtil foi afetada pela escassez de algodão; a de calçados, pelas dificuldades no suprimento de couro (também aqui registrando-se casos de redução da produção); na química, o suprimento deficiente de insumos afetou a produção de resinas (um caso extremo: o fenol, monopolizado pela Rhodia, teve a 
sua produção interrompida em razão da escassez da matéria-prima, importada); a falta de resinas fenólicas e de ferro gusa trouxe dificuldades para a fundição. ${ }^{46}$

Se restasse qualquer dúvida acerca da conjuntura de superaquecimento, bastaria lembrar que as próprias autoridades econômicas o reconheciam. Delfim Netto, falando aos empresários na FIESP, evocaria os "saudosos idos de 63" (quando "sobrava matéria-prima", "sobrava emprego") na tentativa de aplacar o surto de nervosismo ("frenesi", "quase histeria") que se manifestava e insuflar um ânimo positivo, direcionado à continuidade do crescimento. É verdade que

a circunstância de que falta matéria-prima é o indicador mais importante de que estamos batendo no teto da nossa taxa de expansão.

Mas, ele ensinaria:

O desenvolvimento é exatamente isto, é fazer a demanda andar na frente da ofer- ta, porque isto é que estimula os novos investimentos, isto é que dá a rentabilidade às empresas, isto é que dá a escala à indústria.

O compromisso com o crescimento acelerado é inteiramente reafirmado:

Não haveria nada mais simples para o Governo do que fazer desaparecer com um estalar de dedos esta escassez de matéria prima. Simplesmente bastava reduzir a taxa de crescimento. [...] Basta reduqirmos o prazo do recolbimento do IPI para 30 dias [...] Agora eu pergunto: quem é suficientemente inconseqüente para propor uma solução como esta? Quem é suficientemente irresponsável para propor que paralisemos o desenvolvimento econômico só porque existem algumas dificuldades com matéria prima? 47

O período 1972-1973 possui outro traço distintivo: contrastando com a prática anterior, agora a política econômica manifestaria com muita ênfase o

\begin{tabular}{|c|c|c|c|}
\hline $\begin{array}{l}46 \text { Ver para um relato } \\
\text { detalhado: Banas, 10/12/73; } \\
\text { Conjuntura Econômica, fev. 1974; } \\
\text { Visão, 11/6/73 e 24/9/73 } \\
\text { "'São Paulo precisa de reforço", } \\
\text { comentando a escassez de } \\
\text { mão-de-obra não qualificada); } \\
\text { Exame, ago. } 1973 \text { ("Sem } \\
\text { matérias primas, como será o } \\
\text { segundo semestre"). }\end{array}$ & $\begin{array}{l}47 \text { Ver Revista de Finanças } \\
\text { Públicas, out./dez 1973, p. 7-15; } \\
\text { Jornal da Tarde, 13/10/73. } \\
\text { Delfim também apontava a } \\
\text { exacerbação do processo } \\
\text { motivada pela "histeria" - "sair } \\
\text { correndo e pedir a mesma } \\
\text { encomenda a dez fornecedores, } \\
\text { dando a impressão de que existe } \\
\text { dez vezes mais demanda do que }\end{array}$ & $\begin{array}{l}\text { existe. Agindo desta forma, } \\
\text { estamos forçando o teto acima } \\
\text { do qual é impossível subir". Ver } \\
\text { também sua entrevista a Veja, } \\
\text { 4/7/73, onde ele explicitava } \\
\text { suas opções: "Contornar a } \\
\text { pressão através de uma redução } \\
\text { na demanda seria a solução } \\
\text { menos trabalhosa, mas é } \\
\text { preferível adotar caminhos mais }\end{array}$ & $\begin{array}{l}\text { inteligentes, lidando com os } \\
\text { pontos de estrangulamento no } \\
\text { instante em que aparecem. } \\
\text { Aplicar uma política monetária } \\
\text { apertada daria tranqüilidade ao } \\
\text { ministro, mas abandonamos } \\
\text { essa solução em } 1967 \text { e não é } \\
\text { agora que faríamos sua } \\
\text { ressurreição". }\end{array}$ \\
\hline
\end{tabular}


48 Ver Folha de S. Paulo, 16/4/72; o discurso de Médici acha-se em $O$ Estado de $S$.

Paulo, 2/4/72. Um relato feito a posteriori por um integrante da equipe de Delfim informa que os estudos e as avaliações então realizados “[...] nos permitiu concluir da viabilidade de se alcançar uma inflação entre 13 e 18\%; para a meta não ficar vaga, o ministro Delfim resolveu fixá-la em 15\% (a inflação na época rondava persistentemente a barreira dos $20 \%$ e as dificuldades para romper essa barreira eram grandes, principalmente do ponto de vista psicológico)". "Custo de Vida: técnico rompe silêncio", in O Estado de S. Paulo, $1^{\circ} / 10 / 78$.

49 Ver Jornal da Tarde, 6/1/73; O Estado de S. Paulo, $6 / 1 / 73$ e $2 / 1 / 73$ (mensagem de Médici). propósito de redução da inflação, assumindo uma meta explícita, a saber, $15 \%$ em 1972 e 12\% em 1973 (note-se algo que não se via desde o PAEG; mesmo o "golpe mortal" anunciado em 1969 não foi ao ponto de assumir um compromisso com qualquer taxa definida de inflação). O general Médici, discursando no aniversário do regime, daria grande espaço ao tema da inflação, qualificando-a de "mal do século" e "a maior inimiga do bem estar da família brasileira", e anunciaria a adoção de uma "nova postura". Delfim Netto se encarregaria de interpretar a fala presidencial, delimitando a extensão do objetivo:

[...] vamos agora apertar o cerco em torno da inflação. Até agora conseguimos eliminar os efeitos da inflação. É preciso, doravante, atacar as causas do processo inflacionário para eliminar a inflação propriamente dita. [...] Estamos mobilizando a sociedade inteira para a batalh a final contra o inimigo comum. Já conseguimos empurrar a inflação para dentro da jaula. Agora é entrar na jaula e ganhar essa luta de vida ou morte. ${ }^{48}$

No final do ano, o objetivo seria renovado, com o general Médici decretando:

[...] está o governo habilitado a limitar em $12 \%$ o aumento do custo de vida no ano vindouro. Esse - doze por cento - deverá ser, portanto, o nivel máximo da correção monetária em 1973.
Delfim comunicaria ao empresariado sua avaliação das possibilidades em jogo:

Acredito que o desenvolvimento brasileiro, em 1973, será quase automático e seria pouco inteligente de nossa parte ultrapassar a meta de 12\% para a inflação [...] Neste momento, podemos informar que tudo mais está sob controle ao mesmo tempo em que a economia cresce. [...] Quando tudo está sob controle, não há realmente razões para não alcançarmos $12 \%$ de inflação.

E, para deixar definitivamente claro: [...] há condições objetivas para a economia brasileira atingir um nivel inflacionário de 12\%. Qualquer inflação acima disso é puro desperdício. Não precisamos de mais para manter o atual crescimento. Decidiu-se que toda a politica econômica brasileira, em 1973, ao lado do apoio ao crescimento físico, se ajustaria à tarefa de realizar a taxa de inflação de $12 \% .{ }^{49}$

É possível que a decisão de adotar uma "nova postura" diante da inflação na verdade, a recuperação de um ideal originário da Revolução - tenha sido determinada por fatores de ordem política. Sobre isso é possível apenas especular. Indícios sugerindo essa leitura não faltam: a sucessão de Médici já começava a despontar, e a "nova postura" poderia ser uma tática para enquadrar o processo 
ou para aumentar o cacife do grupo dirigente visando influir no seu desenlace final; o regime adotara nesse período uma forma de comunicação baseada no ufanismo aberto, alimentado pelo anúncio de sucessivos "projetos impacto" (PIS, PIN, etc.) - a "nova postura" não deixaria de se revestir desse caráter.

Por outro lado, parece certo que a "nova postura" refletiu um patamar mais elevado do voluntarismo de que o regime se impregnou a partir da tomada de consciência do "milagre". Com efeito: há pouco mais de um ano, incomodado pela fatura que the era lançada pelos devotos da estabilidade, Delfim se permitiu devolver o desafio com o revelador "Preferimos crescer", a melhor síntese do clima característico da administração Médici; agora, ele anunciava o desejo de continuar crescendo ("por muitos anos...") e simultaneamente reduzir expressivamente a inflação, reintroduzindo o sonho da estabilidade. Convenhamos, o governo apostava alto, ao que parece seguro de tudo poder - no mínimo, tratou-se de uma manifestação de audácia.

Mas, de um ângulo estritamente econômico, é plausível admitir que a confiança depositada nas chances de êxito na meta antiinflacionária tenha tido a sua base na aposta em um choque (deflacio- nário) agrícola: veja-se o modelo agrícola-exportador e o vulto das medidas de apoio à agricultura que haviam sido implementadas; recorde-se as repetidas previsões de uma supersafra (a resposta esperada da agricultura) - e é um fato que tal ocorrera em 1971, como que a confirmar o acerto da estratégia em curso. Há indicações de que as autoridades econômicas projetavam excelente desempenho da oferta agrícola em 1972 e novamente em 1973 - isso num momento em que "tudo mais está sob controle" (leia-se: salários domesticados pela política salarial, déficit orçamentário negligível, câmbio acertado, política monetária eficazmente conduzida graças ao open, às minidesvalorizações, etc.)..$^{50} \mathrm{Um}$ segundo elemento teria a ver com a componente psicológica do processo, traduzida por Delfim no comentário "a inflação sempre começa na cabeça das pessoas"; assim, os $20 \%$ de inflação anual terminaram adquirindo caráter de barreira psicológica, "mítica". Dessa forma, tal como a aceleração do crescimento, sustentada na realização de investimentos, dependia da "crença" do empresariado, também a redução da inflação dependia em certa medida da "crença" de que é possível, de que qualquer inflação adicional é desnecessária (um “desperdício”). Delfim Netto era explíci-
50 "As previsões quanto às safras agrícolas do ano que vem já permitem ao governo acreditar que poderemos obter substanciais ganhos no combate à inflação ...” Delfim, em um jantar com banqueiros, Jornal da Tarde, 17/12/71. Ver também: $O$ Estado de S. Paulo, 22/12/71; "O empresário e a inflação de 12\%", in Exame, abr./73; "Custo de Vida: técnico rompe silêncio", in O Estado de S. Paulo, $1^{\circ} / 10 / 78$. 
51 Jornal da Tarde, 6/1/73.

52 "O empresário e a inflação de 12\%", in Exame, abr./73. to a respeito: "Não falta nenhum fator objetivo. Só falta a crença dos homens em que isso seja possível". ${ }^{51}$ Por via das dúvidas, o CIP estaria vigilante para fazer ver aos recalcitrantes que a "nova postura" era para valer.

Assim, para espanto da ortodoxia, a política econômica declarava pretender uma redução significativa da inflação, num gradualismo rápido, e, ao mesmo tempo, perpetuar o crescimento acelerado - portanto, com a manutenção de uma política monetária passiva. Delfim Netto ensinaria (com razão, aliás):

Se é verdade que a inflação começa na cabeça dos homens, também é verdade que, se ela sobrevive por algum tempo, é porque não há outra forma senão sancioná-la pela política monetária, uma vez que a alternativa não é a estabilidade dos preços, como acreditam alguns monetaristas exagerados, mas o desemprego. ${ }^{52}$

Estabilidade monetária sim, mas nada de arrocho fiscal, monetário ou creditício que fatalmente afetariam o ritmo de crescimento. Outros instrumentos que não os convencionais deveriam ser acionados na busca daquele objetivo. Uma breve reconstituição da execução da política econômica não deixa margem para dúvida.

Após a interrupção observada no ano de 1971, prosseguiu em 1972 e 1973 o movimento de redução das taxas de juros (administradas pelo Banco Central). Um conjunto de Resoluções fixou, em fev./72, as novas taxas de juros para as diferentes modalidades de crédito bancário e os rendimentos dos depósitos a prazo e das letras de câmbio. Em jan./73, o Banco Central promoveria novo ciclo de redução das taxas de juros, inclusive a taxa básica de assistência financeira (anteriormente taxa de redesconto), eliminaria o depósito compulsório sobre os depósitos a prazo dos bancos comerciais e o IOF incidente sobre o crédito rural (de custeio ou investimento).

Para além da real eficácia dessas medidas (os mecanismos de reciprocidade desenvolvidos pelo mercado tornavam as taxas de juros efetivas muito superiores aos níveis nominais arbitrados pelo Banco Central) e de suas reais intenções ou funcionalidade, cabe frisar a heterodoxia da política econômica: redução das taxas de juros como instrumento (meio) da pretendida redução da inflação. (Por suposto, plenamente coerente com o objetivo "gêmeo" da preservação do crescimento acelerado.).

Sucessivas portarias ministeriais dariam continuidade à diretriz anterior de conceder prazos sumamente elásticos para o recolhimento do IPI, disponibilizando 
recursos para o financiamento do capital de giro (a custo zero). Inicialmente foram mantidos os prazos de 90 dias para a maior parte das indústrias e de 120 dias para as indústrias têxtil, calçados, ferro fundido e aço; no final de 1972, esses prazos foram alongados para 120 e 150 dias, respectivamente. $\mathrm{O}$ importante é ressaltar a diretriz de manter prazos alongados e até mesmo, em casos específicos, ampliá-los com vigência mais ou menos limitada. Não há registro de qualquer movimento de sentido contrário.

Do ponto de vista dos agregados macroeconômicos, apresenta menos importância a diminuição do déficit orçamentário (com um modesto superávit em 1973) - uma vez que o momento de reversão situou-se em 1969, quando ele atingiu irrisórios $0,6 \%$ do PIB. Assim, o caráter (expansivo) da política fiscal é melhor traduzido pelo expressivo crescimento da despesa pública: 38,3\% em 1972 e 37,4\% em 1973, muito acima da inflação (qualquer que seja o índice utilizado). Esse desempenho não foi acidental, refletindo uma opção deliberada. Com efeito, um crescimento da receita muito além do previsto ensejou uma expansão da despesa também muito acima da previsão orçamentária (em torno de $20 \%$ ), atestando a inexistência de qualquer in- tenção de um manejo compensatório das finanças públicas - atuando, na verdade, de forma pró-cíclica e gerando estímulo semelhante ao previsto no "teorema do orçamento equilibrado".

Quanto às políticas monetária e creditícia, a sua natureza expansiva se acentua notavelmente. De fato, o crescimento dos meios de pagamento atingiu 38,6\% em 1972 e 46,8\% (!) em 1973, não obstante a meta de redução da inflação. Esse desempenho refletiu em parte a crescente demanda de liquidez ("acomodada" pela política monetária), mas, sobretudo, evidenciou as dificuldades para a execução da política econômica, decorrentes do próprio "modelo" adotado. Este, como é sabido, utilizou largamente o endividamento externo, visto como mecanismo de captação de poupança externa, possibilitando elevar a taxa de investimento de forma a assegurar o crescimento acelerado. ${ }^{53}$

Ocorre que o ritmo de expansão do estoque da dívida externa intensificou-se sobremaneira ao longo de 1972 e 1973, ultrapassando as mais otimistas projeções e somente refluindo com a entrada em vigor de um depósito compulsório de 40\% no início de set./73. O seu efeito sobre a acumulação de reservas internacionais foi extremamente forte, ins-

\footnotetext{
53 Da ampla literatura sobre o tema, ver, para um exame detalhado: Carvalho Pereira (1974) e Davidoff Cruz (1984).
} 
tabilizando a condução da política monetária - a despeito da possibilidade de fazer operações de esterilização via open market (refletidas na elevação da relação dívida interna/PIB de 3,7\% em 1969 para 5,6\% em 1971 e 8,0\% em 1973). De fato, um exame dos fatores de expansão da base monetária mostra que o item "operações cambiais" foi o determinante principal ao longo de 1972 e nos primeiros três trimestres de 1973. A expansão da base monetária foi reforçada pelo comportamento dos empréstimos do Banco do Brasil (crescimento de 39\% em 1972 e 49\% em 1973), tornando-se até mesmo o determinante principal no final de 1973 quando os empréstimos externos perdem fôlego. ${ }^{54} \mathrm{E}$, nesse quadro de liquidez farta, a demanda de crédito impulsionada pelo auge é atendida por um crescimento vertiginoso da oferta de crédito (aqui não

54 Ver a análise pormenorizada de Malan (1977) e Relatórios do

Banco Central.

55 Ver Conjuntura Econômica, fev./73 e fev./74; e Relatórios do Banco Central.

56 Ver Carneiro Netto (1976). No auge dos problemas de suprimento de insumos e matérias-primas, um empresário do setor de autopeças manifestaria a

\section{insatisfação reinante: "Está}

cada vez mais difícil dialogar com os funcionários do CIP.

Eles se apresentam com posições prefixadas. Nós compramos chapa de aço desconhece o fato. Quando apresentamos as notas de compra, eles afirmam que não concederam nenhum aumento para o aço". - Banas, $10 / 12 / 73$. acima da tabela e o CIP houve "escassez"): 46\% em 1972 e 43\% em 1973, no caso dos bancos comerciais; 54,4\% em 1972 e 57,3\% em 1973, no caso dos empréstimos do SFH; 65,3\% em 1973, no caso das financeiras (em São Paulo registrou-se a taxa de 108,7\%!) e 60,2\% para os empréstimos dos bancos de investimento. 55

No tocante à política antiinflacionária, além da expectativa de safras agrícolas favoráveis e dos intentos de redução dos juros (visando atuar sobre as tensões de custo), a ação da política econômica se caracterizou por verdadeiro "corpo-a-corpo" com o empresariado, traduzido em sucessivas reuniões das autoridades com representantes de setores da indústria, na tentativa de arrancar um comprometimento com as metas oficiais - em paralelo, o CIP atuaria com rigor redobrado, sobretudo em 1973, quando o número de punições atingiu seu maior índice. ${ }^{56}$ Apenas boa vontade e ameaça de sanções não bastariam. Aproveitando a margem de manobra ensejada pela elasticidade da receita tributária, a política econômica reduziu a zero o IPI incidente sobre produtos alimentícios (através dos Decretos n. 70.435, de 18 de abril de 1972, e n. 70.480, de 4 de maio de 1972). Delfim solicitaria aos dirigentes da indústria e dos supermercados "uma demonstração de que vivemos numa sociedade 
adulta", repassando aos consumidores os benefícios advindos da medida. ${ }^{57}$ No ano seguinte, o Decreto n. 71.728, de 18 de janeiro de 1973, reduziu com amplitude variável (no caso extremo, a redução foi de 50 para $10 \%$ ) as alíquotas de IPI incidentes sobre 30 categorias de produtos, a maior parte concentrada nos setores farmacêutico e material de uso doméstico e de higiene pessoal (dentifrícios, sabonetes, etc.).

$\mathrm{E}$, à medida que começaram a se manifestar os problemas mais agudos de escassez de matérias-primas, especialmente as repercussões domésticas da inflação externa, a política tarifária foi acionada amplamente. Tal se observou sobretudo, em 1973, quando sucessivas resoluções do CPA determinaram a redução (ou isenção) do imposto de importação incidente sobre dezenas de matérias-primas (papel e papelão, alimentos, minérios, couros e peles, matérias-primas químicas, metalúrgicas, etc.). ${ }^{58} \mathrm{E}$ evidente que essa linha de ação tem caráter emergencial: as medidas valem por um período prefixado ou para quantidades determinadas de importações (exemplos: a Resolução n. 1718, de 2 de julho de 1973, isentou de imposto a importação de 80 mil toneladas de folhas de flandres; a Resolução n. 1801, de 11 de setembro de 1973, isentou a importação de 20 mil toneladas de alumínio primário e suas ligas). Enquanto o peso reduzido do imposto de importação na receita tributária dava amplo espaço para o uso desse expediente.

O impacto doméstico da inflação externa se faria por diferentes canais. No

\begin{tabular}{|c|c|c|c|}
\hline $\begin{array}{l}\text { Ver as declarações de Delfim } \\
\text { produzidas in O Estado de } S \text {. } \\
\text { aulo, 21/4/72. Um diretor da } \\
\text { Testlé reconheceria: "A isenção } \\
\text { o IPI constitui, na verdade, } \\
\text { ma providência de alcance } \\
\text { aior do que o empresariado } \\
\text { oderia esperar neste momento, } \\
\text { uando mantinham constantes } \\
\text { ivindicações na área das } \\
\text { enções, mas restringindo-as } \\
\text { uase sempre aos pedidos de } \\
\text { iminuição dos níveis de } \\
\text { icidência tributária". - O } \\
\text { stado de } S . \text { Paulo, } 8 / 4 / 72 \text {. } \\
\text { bserve-se que a isenção do }\end{array}$ & $\begin{array}{l}\text { IPI reduziria, na margem, o } \\
\text { montante do ICM devido - e } \\
\text { ainda influiria sobre os custos } \\
\text { financeiros das empresas. É } \\
\text { incerto, contudo, o resultado } \\
\text { obtido pela medida: o próprio } \\
\text { Delfim Netto, em reunião do } \\
\text { CIP de jan./73, recomendaria } \\
\text { atenção especial para os setores } \\
\text { de industrialização de alimentos, } \\
\text { alegando um comportamento } \\
\text { anormal durante } 1972 .- \text { ver } O \\
\text { Estado de S. Paulo, 16/1/73. } \\
58 \text { Em apenas nove meses de } \\
1973 \text {, cerca de } 128 \text { produtos } \\
\text { foram contemplados com }\end{array}$ & $\begin{array}{l}\text { benefício tarifário - Veja, } \\
\text { 19/9/73, p. 102. Delfim } \\
\text { explicaria, em depoimento no } \\
\text { Congresso Nacional: “[...] a } \\
\text { inflação mundial tem causado } \\
\text { menos repercussão do que seria } \\
\text { de esperar sobre a economia } \\
\text { brasileira. Sendo o Brasil um } \\
\text { país de tarifas bastante elevadas, } \\
\text { a manipulação das tarifas } \\
\text { alfandegárias dos produtos } \\
\text { importados pode neutralizar em } \\
\text { boa parte as elevações externas } \\
\text { dos preços. Isso significa que os } \\
\text { preços externos crescem mais } \\
\text { do que os preços internos. }\end{array}$ & $\begin{array}{l}\text { A explicação reside no fato de que } \\
\text { a baixa da tarifa reduz a pressão da } \\
\text { elevação de preços. No caso dos } \\
\text { metais, por exemplo, reduziram-se } \\
\text { todas as tarifas a zero. No caso } \\
\text { de produtos químicos } \\
\text { reduziram-se as tarifas a 10,12\% } \\
\text { sem que isso representasse o } \\
\text { menor dano à indústria nacional. } \\
\text { O instrumento de manipulação de } \\
\text { tarifas foi usado com muita } \\
\text { freqüência nos últimos seis meses } \\
\text { e creio que ainda existe uma larga } \\
\text { margem de manipulação". (Delfim } \\
\text { Netto, 1973). }\end{array}$ \\
\hline
\end{tabular}


setor agropecuário, a orientação exportadora resultou em forte pressão altista decorrente da tendência à colagem preços domésticos/preços internacionais. Tal era o comprometimento com a meta de redução da inflação que a política econômica não hesitou em adotar restrições às exportações - e, num caso extremo, até mesmo ressuscitar a prática pré- 64 do tabelamento de preços.

O caso mais espetaculoso relacionou-se ao abastecimento de carne bovina. A regra então vigente estabelecia que os pecuaristas deveriam cumprir a relação uma tonelada de carne estocada para uma tonelada exportada (com exceção do Rio Grande do Sul, favorecido pela relação um para três). Durante o segundo semestre de 1972, teve início forte alta dos preços internacionais. Para evitar o ajuste de preços domésticos, o governo introduziu o tabelamento, abandonando-o no início de jan./73, o que ensejou imediata disparada de preços (registrando-se casos em que o aumento ultrapassou $30 \%$ ). Reação do CMN: fixação de uma quota de exportação (implicando uma redução de $40 \%$ sobre o volume exportado em 1972) e imposição de uma quota de contribuição de 200 dólares por tonelada exportada (com vigência de 13/1/73 a 14/12/73). Ao mesmo tempo, reintro- duziu-se o tabelamento; para viabilizar a fixação de preços nos níveis de 1972, concedeu-se uma redução da alíquota de ICM sobre a carne da ordem de $67,7 \%$ seguida, em fevereiro, de isenção de ICM sobre as matérias-primas usadas nas rações animais. O problema não foi resolvido, prosseguindo por todo o ano de 1973: frigoríficos punidos (com corte de crédito e até corte de exportação) por descumprimento do tabelamento; ampliação do crédito durante a entressafra; importações com isenção tarifária para formar estoques reguladores; suspensão das exportações do Centro-Sul; liberação dos preços das carnes "especiais" (filé e alcatra); revisão do tabelamento em dezembro (de Cr $\$ 63,00$ para Cr $\$ 90,00$ a arroba do boi em pé); por fim, portaria da Sunab determinando a requisição de bois nas fazendas em caso de recusa a vender ao preço tabelado (em out./73, a arroba do boi gordo já atingira $\mathrm{Cr} \$ 120,00 \ldots)$.

Problemas análogos atingiram diversos outros produtos. Alguns exemplos:

1. soja (alta de preços de $114 \%$ em 1973): restrição quantitativa de exportação e tabelamento - no final do ano, verificar-se-ia escassez de óleo de soja, suscitando importações com isenção tarifária e tabelamento; 
2. milho: restrição quantitativa e incidência de ICM sobre a exportação, seguida de importações com isenção tarifária;

3. arroz: proibição temporária de exportação (agosto), fixação de quota de exportação (outubro);

4. algodão: restrição quantitativa ou proibição de exportação conforme o tipo de algodão;

5. feijão (alta de preços de 141\% em 1973): importações com isenção tarifária em meados do ano, concessão de preços mínimos mais altos no segundo semestre. ${ }^{59}$

As restrições às exportações também atingiram alguns metais: em meados de 1973, foram limitadas (ou suspensas) as exportações de aço, ferro gusa, cobre, níquel, alumínio, magnésio, zinco e estanho; em seguida, importações com isenção tarifária foram realizadas, visando reverter a escassez de insumos que afetava a indústria. ${ }^{60}$

Por fim, é importante lembrar o uso da política cambial como instrumento da política de combate à inflação. Desde sua introdução em 1968, a sistemática das minidesvalorizações cambiais esteve assentada no princípio da paridade do poder de compra da moeda (minimizando o risco da atividade exportadora).
Com efeito, de 1969 a 1971, a desvalorização cambial anual situou-se em nível pouco superior a $13 \%$, declinando em 1972 para 10,3\%. Já no ano de 1973, a desvalorização anual foi inferior a $0,1 \%$, violando o critério da paridade qualquer que fosse o índice de inflação considerado. Isso foi possibilitado por uma série de fatores: a desvalorização do dólar, a recomposição geográfica dos fluxos de comércio do Brasil, a melhoria dos termos de troca, o conjunto de incentivos à exportação de manufaturados. Mas, sem dúvida, a disposição de incorrer em um "atraso" cambial, transferido para o futuro, decorreu da prioridade atribuída à redução da inflação, perseguida nas condições descritas acima.

O objetivo de redução da inflação, especialmente em 1973, fracassou - o que se tentou ocultar através de um cálculo viciado dos índices de inflação (utilizando para vários itens preços que não refletiam aqueles efetivamente praticados no mercado). As suspeitas nesse sentido tiveram reforço considerável, quando vozes respeitáveis também contestaram a inflação oficial de 1973: um documento do Banco Mundial e um documento interno da administração Geisel, elaborado por Simonsen. Em 1977, a ação do movimento sindical e da oposição ao regime
.

$59 \mathrm{O}$ caso do feijão reflete a tendência a um crescimento desequilibrado da agricultura durante o período, em detrimento das culturas voltadas ao mercado interno. Para uma argumentação nesse sentido, ver Serra (1982) e Cardoso de Mello e Belluzzo (1977).

60 No caso do aço, há informações de que as empresas estatais foram usadas como instrumento da política de combate à inflação - através do rígido controle sobre seus preços e até por atuarem como importadoras de aço, vendido com prejuízo no mercado interno. Ver Banas, $11 / 6 / 73$ e 18/6/73.

Para um relato pormenorizado das dificuldades de abastecimento no ano de 1973 e medidas adotadas, ver "A fábrica contra a fazenda", in Opinião, 18/6/73; “Os problemas do setor externo", in Banas, 16/7/73; Conjuntura Econômica, fev./74. 
$\because \ldots \ldots$

61 Ver o laudo técnico relativo ao processo instaurado contra a Fazenda Nacional pelo Sindicato dos Trabalhadores Metalúrgicos de São Paulo; depoimento de Delfim Netto, in OEstado de S. Paulo,

14/10/78; depoimento de Gil Pace, in O Estado de S. Paulo, 15/10/78. Ver também "Os Arquivos de Delfim", in Isto é Dinheiro n. 325, 19/11/03.

62 Para um desenvolvimento dessa argumentação, ver Lessa (1998). A perspectiva traçada por Lessa nesse trabalho pioneiro (ver item 1.6, p. 62-76) foi a fonte inspiradora de minha investigação (sendo, naturalmente, de minha exclusiva responsabilidade os eventuais erros e deficiências de análise). Ver também a avaliação da política econômica do governo Geisel feita por Delfim, in "Os Arquivos de Delfim”, Isto É Dinheiro n. 325, 19/11/03. abriu extensa discussão em torno da "manipulação dos índices de custo de vida de 1973", desdobrando-se em uma CPI na Câmara Federal; o episódio todo serviu para consolidar a impressão de que a inflação oficial fora subestimada naquele período. ${ }^{61}$

A plena confirmação da meta de crescimento, obtida ano a ano de 1970 a 1973, transformaria o que inicialmente não passara de uma aposta (lembre-se da cautela exibida pelo Planejamento) em convicção cega na continuidade do curso adquirido pela economia brasileira. A autocongratulação e a megalomania surgidas durante o "milagre" ainda teriam uma sobrevida no II PND do governo Geisel. O conteúdo da política econômica, porém, sofreria significativa inflexão. ${ }^{62}$

\section{4_Conclusões}

O governo Médici incorporou a preocupação do regime militar com a aceleração do desenvolvimento econômico num ritmo e duração adequados à meta de superação do subdesenvolvimento - na perspectiva da época, tratava-se da corrida rumo ao ano 2000, oportunidade histórica de cruzar a fronteira do desenvolvimento pleno. Esse projeto nacional aflorou numa conjuntura duplamente favorável - ascenso cíclico, no plano doméstico, e um cenário externo de expansão do comércio e do movimento de capitais possibilitando, assim, desfrutar a evidência de uma economia que crescia na velocidade compatível com as ambições alimentadas pelo regime. Note-se ainda: a recuperação estava em curso desde 1967, mas, somente no início de 1970, vem à tona a evidência do crescimento "milagroso". E há indicações persuasivas de que foi também o momento em que a política econômica concebida por Delfim Netto tornou-se hegemônica, aparecendo o "modelo agrícola-exportador" como a quintessência do projeto Brasil Grande Potência.

É possível argumentar que tal modelo não passou de uma manifestação retórica (afinal, é possível sustentar que o vigoroso dinamismo da economia no período tenha sido gerado aí?). Isso só pode causar estranheza àqueles analistas que ignoram a complexa natureza do processo político-econômico e incidem numa estreita perspectiva que reduz a política econômica a simples aplicação de algum saber econômico. Não se perca de vista, porém, que a execução da política econômica foi coerente com essa retórica: os incentivos à agricultura e à exportação não nasceram então, mas, sem dúvida, ti- 
veram notável ampliação desde o início da administração Médici.

De qualquer forma, a política econômica cumpriu a contento o seu papel de coadjuvar a valorização dos capitais, beneficiando amplo leque de interesses capitalistas. Com certeza em nenhum outro momento desde sua implantação a ditadura logrou atender, de forma tão generosa e ecumênica, as demandas do capital, um fato revelador seja da enorme ampliação do raio de manobra suscitado pelo auge, seja da real natureza da política econômica. Se alguma dúvida houvesse a esse respeito, ela seria facilmente desfeita observando a postura contemporizadora diante da permanência da inflação, num nível suficientemente alto para escandalizar as mentes ortodoxas (e não menos inaceitável para a política econômica delfiniana em 1969...).

Por outro lado, mostrou-se como, em 1972-1973, a política econômica, mesmo colhendo os ambicionados frutos do crescimento acelerado, começaria a se defrontar com obstáculos crescentes à sua execução - até mesmo com os primeiros sinais de fissuras em sua base de apoio (exemplificado pela saída do então ministro da Agricultura, Cirne Lima). Especialmente notável foi o "erro" cometido na condução da política monetária em
1973, comparável ao de 1965 sob o PAEG. Enquanto o objetivo de desinflação, aparentemente imposto à política econômica, terminou sendo perseguido de forma tão artificial quanto a prática atribuída ao populismo pré-1964.

Cabe indicar as lacunas que permanecem na reconstituição da política econômica do período. Em primeiro lugar, a política de fomento à concentração bancária e seu desdobramento no conglomerado financeiro. Além de ter representado substancial modificação da concepção original da reforma financeira de Campos-Bulhões, há indicações (nunca confirmadas pelo próprio Delfim Netto) de que essa evolução indicava um projeto (implícito) mais ambicioso de fortalecimento da grande empresa nacional através da associação banco-indústria. Nessa hipótese, tratar-se-ia de uma peça essencial da estratégia de desenvolvimento do período.

Em segundo lugar, embora o relato oferecido neste artigo tenha destacado a primazia do Ministério da Fazenda na definição e na condução da política econômica, a ação do Planejamento foi intensa, materializando-se em dois documentos: as Metas e Bases para a Ação do Governo (1970) e o I PND (1971). Uma apreciação do papel do Planejamento no período, sobretudo contrastando esses 
documentos com o anterior PED e o posterior II PND, constitui tarefa para futuros estudos.

Finalmente, valeria mencionar ainda uma possibilidade de investigação, utilizando uma metodologia diferente da seguida na pesquisa que originou este artigo. Tendo em vista a notória escassez de relatos detalhados por parte de integrantes da área econômica do governo Médici, há todo um campo aberto para revisão do tema, servindo-se com a amplitude necessária de material colhido mediante entrevistas com ministros e principais integrantes do segundo escalão dos Ministérios econômicos. Embora este artigo se tenha utilizado fartamente da retórica dos policy-makers, apenas as manifestações públicas divulgadas pela grande imprensa e revistas especializadas, assim como alguns poucos documentos, serviram de material de apoio à análise. Da perspectiva deste autor, pesquisadores interessados no tema deveriam considerar seriamente a viabilidade de implementar essa linha de trabalho. 


\section{Referências bibliográficas}

BACHA, Edmar. Os mitos de uma década. Ensaios de Economia Brasileira. Rio de Janeiro:

Paz e Terra, 1976.

BARROS, Geraldo Sant'Ana de Camargo. Investimentos em tratores agrícolas no Brasil. Piracicaba, 1980. Tese de Livre Docência.

Mimeografado.

CARDOSO DE MELLO, João Manuel; BELLUZZO, Luiz Gonzaga de Mello. Reflexões sobre a crise atual. Escrita Ensaio, v. 1, n. 2, 1977.

CARNEIRO NETTO, Dionísio Dias. Política de controle de preços industriais: perspectiva teórica e análise institucional da experiência brasileira. In: Aspectos da participação do governo na economia. Rio de Janeiro: IPEA, Série Monográfica, n. 26, 1976.

CARVALHO PEREIRA, José Eduardo. Financiamento externo e crescimento econômico no Brasil: 1966/73. Rio de Janeiro: IPEA, 1974. (Relatório de Pesquisa, n. 27)

CEFER/IPT. Perfil técnico-econômico do setor de fertilizantes no Brasil. São Paulo, 1980.
DAIN, Sulamis. Aspectos do investimento empresarial do Estado brasileiro: 1969/1975 In: ENCONTRO NACIONAL DE ECONOMIA, 7., 1979, Atibaia (SP). Anais... ANPEC: Atibaia, 1979

\section{DAVIDOFF CRUZ, Paulo.}

Divida externa e política econômica.

A experiência brasileira nos anos

70. São Paulo: Brasiliense, 1984

\section{DELFIM NETTO, Antonio.}

Problemas da economia brasileira.

Brasília: Ministério da Fazenda, 1973. Mimeografado.

DIAS LEITE, Antonio. O

Programa de Ação Econômica do Governo em face da realidade nacional. In: $O$ debate do Programa de Ação. Rio de Janeiro: CONSPLAN, 1965. (Documento de Trabalho, n. 3).

IANNI, Octavio. Estado e planejamento econômico no Brasil (1930-1970). 2. ed. Rio de Janeiro: Civilização Brasileira, 1977.

IPT. Avaliação e perspectivas do comportamento da demanda de fertilizantes no Brasil. São Paulo, 1981.

LESSA, Carlos. A estratégia de desenvolvimento 1974-1976: sonho e fracasso. 2. ed. Campinas: IE-UNICAMP, 1998.
LOLOIAN, Alexandre Jorge. Um estudo do Fundo PIS / PASEP. Campinas: Dissertação de Mestrado, 1980. Mimeografado.

MACARINI, José Pedro. A política econômica da ditadura militar no limiar do "milagre" brasileiro: 1967/69. Campinas:

IE/UNICAMP, set. 2000.

(Texto para Discussão, n. 99).

MALAN, Luis. Aspectos do controle de liquidez na economia brasileira. Brasília: Dissertação de Mestrado, 1977. Mimeografado.

MANDEL, Ernest. La crisis. 2. ed. Barcelona: Editorial Fontamara, 1977.

MEDICI, Emílio Garrastazu. O jogo da verdade. Brasília: Imprensa Nacional, 1970.

SERRA, José. Ciclos e mudanças estruturais na economia brasileira do pós-guerra. Revista de Economia Politica, n. 6, abr./jun. 1982.

SIMONSEN, Mário Henrique. Brasil 2001. Rio de Janeiro: Apec Editora, 1969.

VINHAS DE QUEIROZ,

Maurício. Brasil e Japão: analogias e contrastes históricos. Debate \& Critica, n. 1, 1973.

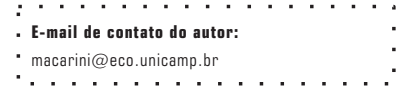

-macarini@eco.unicamp.br 